University of Louisville ThinkIR: The University of Louisville's Institutional Repository

Electronic Theses and Dissertations

$12-2013$

\title{
Anxiety in children with Williams syndrome : association with negative reactivity, self-regulation, and sensory modulation.
}

Nicole A. Crawford-Zelli

University of Louisville

Follow this and additional works at: https://ir.library.louisville.edu/etd

Part of the Psychiatry and Psychology Commons

\section{Recommended Citation}

Crawford-Zelli, Nicole A., "Anxiety in children with Williams syndrome : association with negative reactivity, self-regulation, and sensory modulation." (2013). Electronic Theses and Dissertations. Paper 2280.

https://doi.org/10.18297/etd/2280

This Doctoral Dissertation is brought to you for free and open access by ThinkIR: The University of Louisville's Institutional Repository. It has been accepted for inclusion in Electronic Theses and Dissertations by an authorized administrator of ThinkIR: The University of Louisville's Institutional Repository. This title appears here courtesy of the author, who has retained all other copyrights. For more information, please contact thinkir@louisville.edu. 


\title{
ANXIETY IN CHILDREN WITH WILLIAMS SYNDROME: ASSOCIATION WITH NEGATIVE REACTIVITY, SELF-REGULATION, AND SENSORY MODULATION
}

\author{
By \\ Nicole A. Crawford-Zelli \\ B.A., Keene State College, 2004 \\ M.A., University of Louisville, 2008
}

\begin{abstract}
A Dissertation
Submitted to the Faculty of the

College of Arts and Sciences of the University of Louisville

In Partial Fulfillment of the Requirements

For the Degree of
\end{abstract}

Doctor of Philosophy

Department of Psychological and Brain Sciences

University of Louisville

Louisville, KY

December 2013 
Copyright 2013 by Nicole A. Crawford-Zelli

All rights reserved 



\begin{abstract}
ANXIETY IN CHILDREN WITH WILLIAMS SYNDROME: ASSOCIATION WITH NEGATIVE REACTIVITY, SELF-REGULATION, AND SENSORY MODULATION

By

Nicole A. Crawford-Zelli

B.A., Keene State College, 2004

M.A., University of Louisville, 2008

A Dissertation Approved on
\end{abstract}

December 4, 2013

by the following Dissertation Committee:

Carolyn B. Mervis, Ph.D.

Dissertation Director

Janet Woodruff-Borden, Ph.D.

Cara H. Cashon, Ph.D.

Paul Salmon, Ph.D.

Jill L. Adelson, Ph.D. 


\section{ACKNOWLEDGEMENTS}

The following people helped make this dissertation possible, and I would like to express my gratitude:

- Dr. Carolyn B. Mervis, my advisor, mentor, and dissertation chair who has supported and guided me throughout my graduate career. Thank you for encouraging me to be a better scientist, writer, and to reach my academic potential.

- Dr. Janet Woodruff-Borden, Dr. Jill Adelson, Dr. Cara Cashon, and Dr. Paul Salmon, the members of my dissertation committee, for their ongoing support, feedback, and contributions to this project.

- The federal funding agencies that supported this research: National Institute of Child Health and Human Development grant \#R37 HD29957 (Carolyn B. Mervis, PI) and National Institute of Neurological Disorders and Stroke grant \#R01 NS35102 (Carolyn B. Mervis, PI).

- The families of the children with Williams syndrome for their participation in this project.

- Members of the Neurodevelopmental Sciences Lab, past and present, for their help with ongoing data collection and management. 
- Finally, my family: my husband, Anthony Zelli, for supporting and encouraging me every step of the way, and my parents, Annette and Daniel Crawford, for teaching me the value of education and spending countless hours caring for my baby so I could complete this project. 


\begin{abstract}
ANXIETY IN CHILDREN WITH WILLIAMS SYNDROME: ASSOCIATION WITH NEGATIVE REACTIVITY, SELF-REGULATION, AND SENSORY MODULATION
\end{abstract}

Nicole A. Crawford-Zelli

December 4, 2013

Williams syndrome (WS) is a neurodevelopmental disorder caused by a submicroscopic deletion of approximately 25 genes on chromosome 7q11.23 (Hillier et al., 2003). This genotype is associated with a characteristic set of phenotypic features including mild to moderate intellectual disability, a distinctive cognitive profile, facial dysmorphology, common personality traits, cardiovascular problems, and connective tissue disorders (Morris, 2010). In addition, behavioral difficulties such as anxiety symptoms (e.g., Leyfer, Woodruff-Borden, \& Mervis, 2009), negative reactivity (e.g., Davies, Udwin, \& Howlin, 1998), problems with self-regulation (e.g., Woodruff-Borden, Kistler, Henderson, Crawford, \& Mervis, 2010), and sensory modulation difficulties (e.g., John \& Mervis, 2010) are common. While anxiety as a behavioral concern for individuals with WS is well-documented, little is known about why these individuals are at an increased risk for this type of problem. Several features of the WS behavioral phenotype have been associated with child anxiety in the general population, specifically negative reactivity (e.g., Lonigan, Phillips, \& Hooe, 2003), self-regulation problems (e.g., Eisenberg et al., 2001), and sensory modulation difficulties (e.g., Ben-Sasson, Cermak, Orsmond, Tager-Flusberg, Kadlec, \& Carter, 2008). The purpose of this dissertation was 
to explore the relations of negative reactivity (NR), difficulties with self-regulation (SR), and sensory modulation difficulties (SM) to the increased prevalence of anxiety symptoms in children with WS. Study hypotheses are: (1) The shared variance between NR, SR, and SM will be adequately represented by a single underlying 'behavioral phenotype' factor. (2) This factor will share a significant relation with anxiety symptoms in children with WS.

Participants were 115 children with WS aged $6-10$ years. Primary caregivers completed four measures: (1) Children's Behavior Questionnaire (Rothbart, Ahadi, Hershey, \& Fisher, 2001). NR was measured using the Negative Affectivity factor score. (2) Short Sensory Profile (McIntosh, Miller, Shyu, \& Dunn, 1999). SM was measured using the Total Sensory Modulation score. (3) Behavior Rating Inventory of Executive Functioning (Gioia, Isquith, Guy, \& Kenworthy, 2000). SR was measured using the Behavioral Regulation Index T-score. (4) Child Behavior Checklist 6 - 18 (Achenbach \& Rescorla, 2001). Anxiety symptoms were measured using the DSM-IV Anxiety Problems T-score.

Exploratory factor analysis and regression analysis were conducted to test the study hypotheses. The results supported both hypotheses: The WS behavioral phenotype features of negative reactivity, difficulties with sensory modulation, and difficulties with self-regulation were adequately represented by one underlying factor; and this factor explained a substantial portion of the variance in anxiety symptoms for children with WS aged $6-10$ years. Implications for future research and treatment of anxiety in children with WS are discussed. 
TABLE OF CONTENTS

PAGE

ACKNOWLEDGEMENTS........................................................................... iii

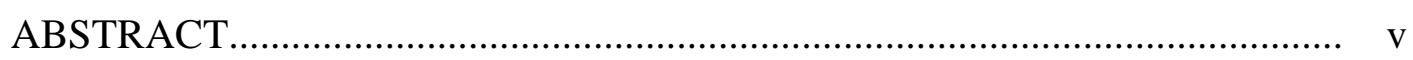

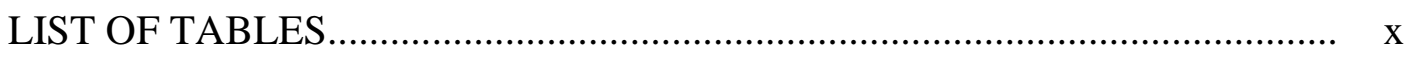

LIST OF FIGURES...............................................................................

CHAPTER

I. GENERAL INTRODUCTION..................................................... 1

Anxiety in Individuals with Williams Syndrome........................... 3

Williams Syndrome Phenotype: Neurobiological Findings........... 21

Negative Reactivity .............................................................. 24

Self-Regulation Problems......................................................... 28

Sensory Modulation Difficulties................................................... 31

Dissertation Project................................................................ 34

II. METHODS AND RESULTS ........................................................ 36

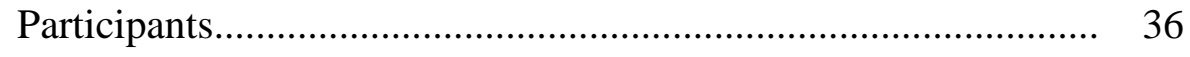




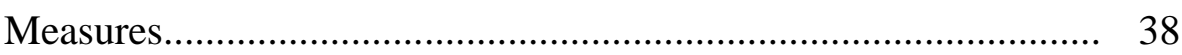

Results: Descriptive Statistics...................................................... 40

Results: Hypothesis 1............................................................. 43

Results: Hypothesis 2 2......................................................... 46

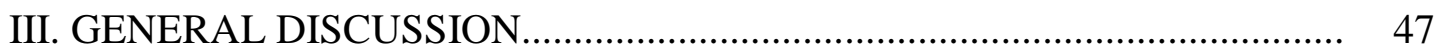

Williams Syndrome ‘Behavioral Phenotype' Factor...................... 47

Association Between Williams Syndrome 'Behavioral

Phenotype' Factor and Anxiety Symptoms......................... 49

Implications for Future Research.............................................. 51

Implications for Treatment of Anxiety in Williams Syndrome...... 56

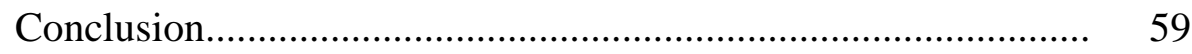

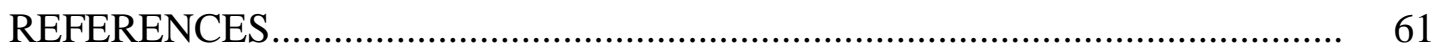

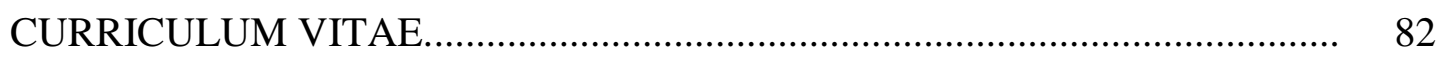




\section{LIST OF TABLES}

TABLE

PAGE

1. Key Findings Regarding Anxiety in Individuals with Williams Syndrome....

2. Descriptive Statistics for Negative Reactivity, Sensory Modulation

Difficulties, Self-Regulation Problems, and Anxiety Symptoms..............

3. Pearson Correlations Between Chronological Age, IQ, Negative Reactivity, Sensory Modulation Difficulties, Self-Regulation Problems, and

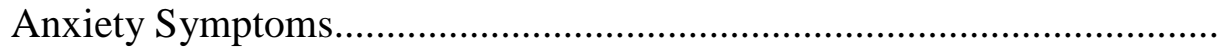

4. Parallel Analysis Results.. 45 


\section{LIST OF FIGURES}

1. Schematic Depiction of Structural Framework for Conceptualizing

Psychiatric Symptoms/Disorders..................................................... 20

2. OFC-Limbic System Neural Circuitry ............................................................ 23

3. Schematic Depiction of Theoretical Pathway for Anxiety in Williams

Syndrome 


\section{CHAPTER I}

\section{GENERAL INTRODUCTION}

Williams syndrome (WS) is a neurogenetic developmental disorder caused by a submicroscopic deletion of approximately 25 genes on chromosome 7q11.23 (Hillier et al., 2003). WS is associated with a characteristic set of phenotypic features which include mild to moderate intellectual disability, a distinctive cognitive profile, facial dysmorphology, common personality traits, cardiovascular problems such as supravalvar aortic stenosis (SVAS), and connective tissue disorders (Morris, 2010). In addition, anxiety symptoms (Leyfer, Woodruff-Borden, Klein-Tasman, Fricke, \& Mervis, 2006; Leyfer, Woodruff-Borden, \& Mervis, 2009), negative reactivity (Davies, Udwin, \& Howlin, 1998; John \& Mervis, 2010; Tomc, Williamson, \& Pauli, 1990; Udwin, Howlin, Davies, \& Mannion, 1998), problems with self-regulation (Arnold, Yule, \& Martin, 1985; Davies et al., 1998; Dilts, Morris, \& Leonard, 1990; Gosch \& Pankau, 1994; Tomc et al., 1990; Udwin, 1990; Woodruff-Borden, Kistler, Henderson, Crawford, \& Mervis, 2010), and sensory modulation difficulties (Dilts et al., 1990; Gallo, Klein-Tasman, Gaffrey, \& Curran, 2008; John \& Mervis, 2010) are common. As with most phenotypes, substantial variability exists in the expression of these characteristics (Morris, 2010). The purpose of this study is to explore the relation of three behavioral phenotype factors associated with WS - negative reactivity, self-regulation problems, and sensory modulation difficulties to anxiety symptoms in children with this syndrome. 
Anxiety may be conceptualized as an umbrella term that includes anxiety symptoms, clinical anxiety disorders, and anticipatory fears (Eley \& Gregory, 2004). Anxiety symptoms result from the affective experience of anxiety defined as "futureoriented emotion, characterized by perceptions of uncontrollability and unpredictability over potentially aversive events and a rapid shift in attention to the focus of potentially dangerous events or one's own affective response to these events" (Barlow, 2002, p. 104). When anxiety symptoms become chronic, cause consistent distress, and interfere with daily activities, a clinical diagnosis of an anxiety disorder is made. Anxiety symptoms are differentiated from situational fear, which is classified by an automatic and innate nervous system response to present danger (Barlow, 2002). Individuals with WS commonly experience anxiety symptoms, and anxiety disorders are more prevalent among children with WS than among either typically developing (TD) children or children with intellectual disabilities (ID) of mixed etiology (Leyfer et al., 2006; Leyfer et al., 2009; Udwin, 1990). Leyfer et al. (2009) estimated the prevalence of DSM-IV anxiety disorders in children and adolescents with WS as: specific phobia: $56.1 \%$, generalized anxiety: $7.6 \%$, separation anxiety: $6.1 \%$, obsessive-compulsive disorder: $1.5 \%$, social phobia: $2.3 \%$, and post-traumatic stress disorder: $1.5 \%$. In contrast, the estimated prevalence rates for anxiety disorders in children in the TD population (Shaffer et.al., 1996; Zohar, 1999) and the ID population (Dekker \& Koot, 2003) are as follows: specific phobia: $1.3 \%$ (TD), $6.8 \%$ (ID); generalized anxiety: $3.1 \%$ (TD), $0 \%$ (ID); separation anxiety: 2.3\% (TD), 1.9\% (ID); obsessive-compulsive disorder: 2-4\% (TD), $1.5 \%$, and social phobia: $4.5 \%$ (TD), $1.9 \%$ (ID). 
Although the existence of anxiety problems among individuals with WS is welldocumented, the nature of this problem remains to be understood. Research findings from 7q11.23 knock-out mice (Hoogenraad et al., 2002; Li et al., 2009; Meng et al., 2002; Mervis et al., 2012), increased anxiety prevalence in children with 7q11.23 duplication syndrome (Mervis et al., 2012; Henderson, Crawford-Zelli, WoodruffBorden, \& Mervis, 2014; Velleman \& Mervis, 2011), and neuroimaging studies of adults with WS who have IQs in the average range for the general population (MeyerLindenberg et al., 2005; Meyer-Lindenberg et al., 2004) provide evidence for an increased genetic risk of anxiety associated with one or more genes in the WS region. The purpose of this dissertation is to investigate the associations of three characteristics included in the 7q11.23 deletion behavioral phenotype - negative reactivity, selfregulation difficulties, and sensory modulation difficulties - with anxiety symptoms in children with WS. In the remainder of this introduction I review the literature on anxiety in individuals with WS, followed by a description of psychiatric concerns found in individuals with 7q11.23 duplication syndrome. An exploration of the WS phenotype follows, examining potential links of negative affectivity, problems with self-regulation, and sensory modulation difficulties to anxiety based on supporting theoretical and empirical evidence from studies of TD children and children with autism. At the end of the chapter, I state the hypotheses to be tested in this dissertation.

\section{Anxiety in Individuals with Williams Syndrome}

Anxiety symptoms are commonly experienced in childhood and have been theorized to serve an adaptive evolutionary purpose for survival (Barlow, 2002; Last, Perrin, Hersen, \& Kazdin, 1996). Anxiety disorders are differentiated from typical 
anxiety experiences by their level of chronicity, duration, and clinical impairment in social, occupational, or adaptive functioning (Dweck \& Wortman, 1982; Last, Hansen, \& Franco, 1997; Strauss, Frame, \& Forehand, 1987). Childhood anxiety disorders are one of the most commonly diagnosed psychiatric problems, with lifetime prevalence rates estimated between 10\% and 25\% (Anderson, Williams, McGee, \& Silva, 1987; Kashani \& Orvaschel, 1990; Robins, 1984). Many anxiety disorders display a chronic course with an onset during childhood (Burke, Burke Jr, Regier, \& Rae, 1990; Keller, Lavori, Wunder, Beardslee, Schwartz, \& Roth, 1992; Last et al., 1996; Ollendick \& King, 1994). The Diagnostic and Statistical Manual of Psychiatric Disorders Fourth Edition (APA, 2000) recognizes seven anxiety disorders as occurring in childhood. These include separation anxiety, specific phobia, social phobia, generalized anxiety disorder, posttraumatic stress disorder, obsessive-compulsive disorder, and acute stress disorder. As previously mentioned, anxiety is considered a common feature of the WS behavioral phenotype (e.g., Morris, 2010). The publications that have examined anxiety in samples of individuals with WS are listed in Table 1, in alphabetical order by author. Sample characteristics, assessment measures, and key findings are described. The majority of studies reports anxiety as a common emotional difficulty and one of the most frequently endorsed behavioral problems. Caregiver-report questionnaire is the primary mode of assessment, with results indicating elevated anxiety symptoms in comparison to TD individuals and individuals with ID of mixed etiology across a wide age range. Studies that have used an interview format have found similar results. The most frequently reported anxiety concerns include chronic fearfulness, symptoms of specific 
phobia, generalized worry about physical harm to self and others, and anticipatory worry about future events.

\section{Table 1}

Key Findings Regarding Anxiety in Individuals with Williams Syndrome

\begin{tabular}{|c|c|c|c|c|}
\hline Author(s) & $n$ & Age Range & Measures & Key Findings \\
\hline $\begin{array}{l}\text { Arnold, } \\
\text { Yule, \& } \\
\text { Martin } \\
(1985)\end{array}$ & 23 & $7-13$ years & $\begin{array}{l}\text { Rutter Scales for } \\
\text { Parents and Teachers } \\
\text { (Rutter, Tizard, \& } \\
\text { Whitmore, 1970) }\end{array}$ & $\begin{array}{l}\text { Clinical levels of anxiety } \\
\text { symptoms demonstrated in } \\
30 \% \text { of individuals with } \\
\text { WS. }\end{array}$ \\
\hline $\begin{array}{l}\text { Cherniske et } \\
\text { al. (2004) }\end{array}$ & 20 & $30-52$ years & $\begin{array}{l}\text { Semi-structured and } \\
\text { open-ended clinical } \\
\text { interviews }\end{array}$ & $\begin{array}{l}\text { (1) } 95 \% \text { of individuals } \\
\text { with WS displayed clinical } \\
\text { levels of anxiety } \\
\text { symptoms. } \\
\text { (2) A subset ( } \mathrm{n}=18 \text { ) of } \\
\text { individuals with WS } \\
\text { received clinical } \\
\text { interviews; } 72 \% \text { of these } \\
\text { individuals displayed } \\
\text { moderate-severe levels of } \\
\text { anxiety, and } 16 \% \\
\text { displayed mild/subclinical } \\
\text { levels. } 50 \% \text { of these } \\
\text { individuals met diagnostic } \\
\text { criteria for specific phobia }\end{array}$ \\
\hline $\begin{array}{l}\text { Davies, } \\
\text { Udwin, \& } \\
\text { Howlin } \\
(1998)\end{array}$ & 70 & $9-39$ years & $\begin{array}{l}\text { Social and Emotional } \\
\text { Functioning Interview } \\
\text { (Mawhood, 1995) }\end{array}$ & $\begin{array}{l}\text { Phobia symptoms reported } \\
\text { in } 50 \% \text { of individuals with } \\
\text { WS, with clinical } \\
\text { impairment in } 41 \% \text { of } \\
\text { sample. }\end{array}$ \\
\hline
\end{tabular}




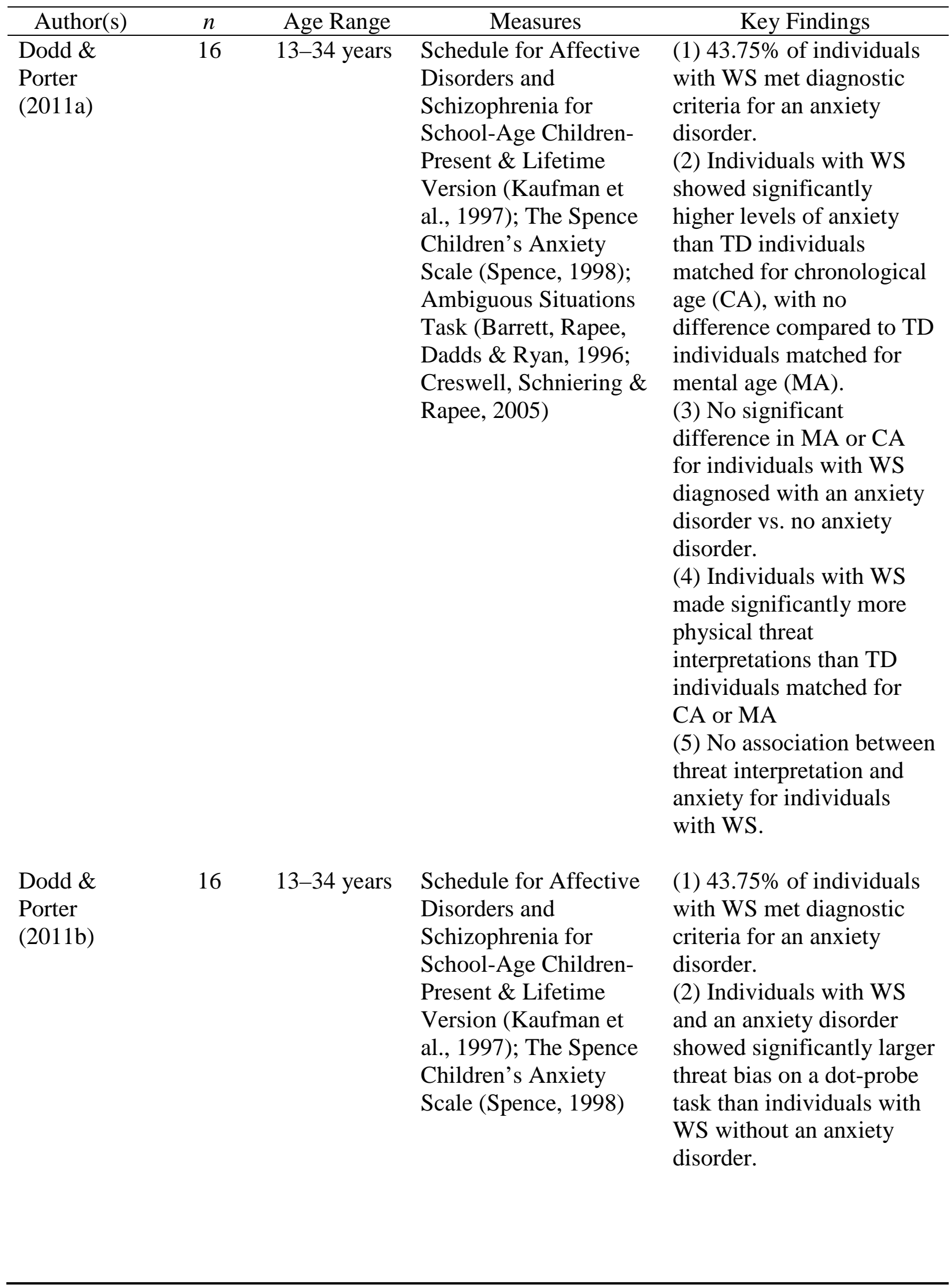




\begin{tabular}{|c|c|c|c|c|}
\hline Author(s) & $n$ & Age Range & Measures & Key Findings \\
\hline $\begin{array}{l}\text { Dodd, } \\
\text { Schniering } \\
\text { \& Porter } \\
(2009)\end{array}$ & 15 & $12-28$ years & $\begin{array}{l}\text { Schedule for Affective } \\
\text { Disorders and } \\
\text { Schizophrenia for } \\
\text { School-Age Children- } \\
\text { Present \& Lifetime } \\
\text { Version (Kaufman et } \\
\text { al., 1997); The Spence } \\
\text { Children's Anxiety } \\
\text { Scale (Spence, 1998); } \\
\text { The Children's } \\
\text { Automatic Thoughts } \\
\text { Scale (Schniering \& } \\
\text { Rapee, 2002) }\end{array}$ & $\begin{array}{l}\text { (1) } 40 \% \text { of individuals } \\
\text { with WS met diagnostic } \\
\text { criteria for specific phobia, } \\
6 \% \text { met for generalized } \\
\text { anxiety disorder. } \\
\text { (2) Individuals with WS } \\
\text { displayed significantly } \\
\text { higher levels of } \\
\text { generalized anxiety than } \\
\text { TD individuals matched on } \\
\text { MA with no anxiety } \\
\text { disorders. } \\
\text { (3) Individuals with WS } \\
\text { displayed similar levels of } \\
\text { social anxiety as TD } \\
\text { individuals matched on } \\
\text { MA with no anxiety } \\
\text { disorders. } \\
\text { (4) Individuals with WS } \\
\text { displayed significantly } \\
\text { lower levels of social } \\
\text { anxiety and generalized } \\
\text { anxiety than TD } \\
\text { individuals matched on } \\
\text { MA with an anxiety } \\
\text { disorder. } \\
\text { (5) Individuals with WS } \\
\text { reported significantly more } \\
\text { thoughts related to } \\
\text { physical threat than TD } \\
\text { individuals matched on } \\
\text { MA with and without } \\
\text { anxiety disorders. }\end{array}$ \\
\hline
\end{tabular}




\begin{tabular}{|c|c|c|c|c|}
\hline Author(s) & $n$ & Age Range & Measures & Key Findings \\
\hline $\begin{array}{l}\text { Dykens } \\
(2003)- \\
\text { study } 1\end{array}$ & 120 & $6-48$ years & $\begin{array}{l}\text { Fear Survey Schedule } \\
\text { for Children-Revised } \\
\text { (parent report; } \\
\text { Ollendick, 1983; } \\
\text { Ollendick, King, \& } \\
\text { Frary, 1989) }\end{array}$ & $\begin{array}{l}\text { (1) WS group showed } \\
\text { significantly more fears } \\
\text { than CA- and IQ-matched } \\
\text { group on all fear factors. } \\
\text { (2) Females with WS had } \\
\text { more fears than males with } \\
\text { WS. } \\
\text { (3) Both the WS group and } \\
\text { the CA- and IQ- matched } \\
\text { group showed age-related } \\
\text { increases in fears. }\end{array}$ \\
\hline $\begin{array}{l}\text { Dykens } \\
(2003)- \\
\text { study } 2\end{array}$ & 36 & $8-39$ years & $\begin{array}{l}\text { Fear Survey Schedule } \\
\text { for Children-Revised } \\
\text { (child interview } \\
\text { format; Ollendick, } \\
\text { 1983; Ollendick et al. } \\
\text { 1989) }\end{array}$ & $\begin{array}{l}\text { Individuals with WS } \\
\text { demonstrated significantly } \\
\text { more fears than CA- and } \\
\text { IQ- matched individuals on } \\
\text { all factors except medical } \\
\text { fears. }\end{array}$ \\
\hline $\begin{array}{l}\text { Dykens } \\
(2003)- \\
\text { study } 3\end{array}$ & 51 & 5-49 years & $\begin{array}{l}\text { Diagnostic Interview } \\
\text { Schedule for Children- } \\
\text { Parent (Reich, Shayka } \\
\text { \& Tailbeson, 1991) }\end{array}$ & $\begin{array}{l}\text { Individuals with WS } \\
\text { frequently met diagnostic } \\
\text { criteria for anxiety } \\
\text { disorders (specific phobia: } \\
35 \% \text {, generalized anxiety } \\
\text { disorder: } 18 \% \text {, separation } \\
\text { anxiety disorder: } 4 \% \text {, } \\
\text { obsessive-compulsive } \\
\text { disorder: } 2 \% \text { ). }\end{array}$ \\
\hline $\begin{array}{l}\text { Dykens \& } \\
\text { Rosner } \\
(1999)\end{array}$ & 35 & $14-50$ years & $\begin{array}{l}\text { Reiss Profiles of } \\
\text { Fundamental Goals } \\
\text { and Motivation } \\
\text { Sensitivities for } \\
\text { Persons with Mental } \\
\text { Retardation (parent } \\
\text { report; Reiss \& } \\
\text { Havercamp, 1998) }\end{array}$ & $\begin{array}{l}\text { (1) Individuals with WS } \\
\text { displayed comparable } \\
\text { levels of anxiety as a group } \\
\text { of similarly- aged } \\
\text { individuals with Prader- } \\
\text { Willi syndrome and group } \\
\text { of similarly-aged } \\
\text { individuals with ID of } \\
\text { mixed etiology. } \\
\text { (2) Individuals with WS } \\
\text { scored significantly higher } \\
\text { than individuals with } \\
\text { Prader-Willi syndrome and } \\
\text { individuals with ID of } \\
\text { mixed etiology on item } \\
\text { "has many fears." }\end{array}$ \\
\hline
\end{tabular}




\begin{tabular}{|c|c|c|c|c|}
\hline Author(s) & $n$ & Age Range & Measures & Key Findings \\
\hline $\begin{array}{l}\text { Dykens, } \\
\text { Rosner, Ly, } \\
\text { \& Sagun } \\
(2005)- \\
\text { study } 1\end{array}$ & 31 & $\begin{array}{l}\text { Mean age } \\
10.22 \text { years } \\
\text { (no range } \\
\text { reported) }\end{array}$ & $\begin{array}{l}\text { Child Behavior } \\
\text { Checklist (Achenbach, } \\
\text { 1991); Parent and child } \\
\text { interview about } \\
\text { musicality }\end{array}$ & $\begin{array}{l}\text { (1) Individuals with WS } \\
\text { displayed significantly } \\
\text { higher levels of anxiety } \\
\text { than similarly-aged } \\
\text { individuals with Down } \\
\text { syndrome. } \\
\text { (2) Anxiety level was not } \\
\text { significantly different for } \\
\text { individuals with WS } \\
\text { compared to similarly- } \\
\text { aged individuals with } \\
\text { Prader-Willi syndrome. } \\
\text { (3) Playing an instrument } \\
\text { and singing in a choir } \\
\text { were associated with } \\
\text { lower levels of anxiety for } \\
\text { individuals with WS. }\end{array}$ \\
\hline $\begin{array}{l}\text { Dykens, } \\
\text { Rosner, Ly, } \\
\text { \& Sagun } \\
(2005)- \\
\text { study } 2\end{array}$ & 26 & $\begin{array}{l}\text { Mean age } \\
20.88 \text { years } \\
\text { (no range } \\
\text { reported) }\end{array}$ & $\begin{array}{l}\text { Child Behavior } \\
\text { Checklist (Achenbach, } \\
\text { 1991); Fear Survey } \\
\text { Schedule for Children- } \\
\text { Revised (child } \\
\text { interview format; } \\
\text { Ollendick et al. 1989); } \\
\text { Multidimensional } \\
\text { Anxiety Scale for } \\
\text { Children (March, } \\
\text { Parker, Sullivan, } \\
\text { Stallings, \& Connors, } \\
\text { 1997); Parent and child } \\
\text { interview about } \\
\text { musicality }\end{array}$ & $\begin{array}{l}\text { (1) Individuals with WS } \\
\text { displayed significantly } \\
\text { higher levels of anxiety } \\
\text { than similarly-aged } \\
\text { individuals with Down } \\
\text { syndrome. } \\
\text { (2) Anxiety level was not } \\
\text { significantly different for } \\
\text { individuals with WS } \\
\text { compared to similarly- } \\
\text { aged individuals with } \\
\text { Prader-Willi syndrome. } \\
\text { (3) Individuals with WS } \\
\text { displayed significantly } \\
\text { more fears than similarly- } \\
\text { aged individuals with } \\
\text { Down syndrome or } \\
\text { Prader-Willi syndrome. } \\
\text { (4) Increased duration of } \\
\text { playing an instrument } \\
\text { and higher perceived skill } \\
\text { in playing an instrument } \\
\text { were associated with } \\
\text { decreased anxiety level } \\
\text { for individuals with WS. }\end{array}$ \\
\hline
\end{tabular}




\begin{tabular}{|c|c|c|c|c|}
\hline Author(s) & $n$ & Age Range & Measures & Key Findings \\
\hline $\begin{array}{l}\text { Einfeld, } \\
\text { Tonge, \& } \\
\text { Florio } \\
(1997)\end{array}$ & 70 & $\begin{array}{l}\text { Mean age } \\
9.2 \text { years (no } \\
\text { range } \\
\text { reported) }\end{array}$ & $\begin{array}{l}\text { Developmental } \\
\text { Behaviour Checklist- } \\
\text { Primary Carer Version } \\
\text { (Einfeld \& Tonge, } \\
\text { 1994) }\end{array}$ & $\begin{array}{l}\text { Individuals with WS } \\
\text { displayed significantly } \\
\text { higher levels of anxiety than } \\
\text { similarly-aged } \\
\text { epidemiological sample of } \\
\text { individuals with ID. }\end{array}$ \\
\hline $\begin{array}{l}\text { Einfeld, } \\
\text { Tonge, \& } \\
\text { Rees } \\
(2001)\end{array}$ & $\begin{array}{l}\text { Time 1: } \\
64 \\
\text { Time 2: } \\
53\end{array}$ & $\begin{array}{l}\text { Mean age } \\
\text { Time 1: } 9.4 \\
\text { years; } \\
\text { Mean age } \\
\text { Time 2: } 14.5 \\
\text { years (no } \\
\text { range } \\
\text { reported) }\end{array}$ & $\begin{array}{l}\text { Developmental } \\
\text { Behaviour Checklist- } \\
\text { Primary Carer Version } \\
\text { (Einfeld \& Tonge, } \\
\text { 1994) }\end{array}$ & $\begin{array}{l}\text { (1) Individuals with WS } \\
\text { displayed significantly } \\
\text { higher levels of anxiety than } \\
\text { similarly-aged } \\
\text { epidemiological sample of } \\
\text { individuals with ID at both } \\
\text { time points. } \\
\text { (2) Individuals with WS } \\
\text { showed no significant } \\
\text { change in anxiety level } \\
\text { across time. }\end{array}$ \\
\hline $\begin{array}{l}\text { Gagliardi, } \\
\text { Martelli, } \\
\text { Tavano, \& } \\
\text { Borgatti } \\
(2011)\end{array}$ & 41 & 2.5-29 years & $\begin{array}{l}\text { Developmental } \\
\text { Behaviour Checklist- } \\
\text { Parent Version } \\
\text { (Einfeld \& Tonge, } \\
\text { 2002) }\end{array}$ & $\begin{array}{l}\text { (1) Anxiety was the most } \\
\text { frequently endorsed } \\
\text { behavioral concern for } \\
\text { individuals with WS. } \\
\text { (2) Individuals with WS } \\
\text { showed no significant } \\
\text { change in anxiety level } \\
\text { across age. } \\
\text { (3) Individuals with WS } \\
\text { showed no significant } \\
\text { association between } \\
\text { cognitive abilities and } \\
\text { anxiety level. }\end{array}$ \\
\hline $\begin{array}{l}\text { Gosch \& } \\
\text { Pankau } \\
(1994)\end{array}$ & 19 & 4-10 years & $\begin{array}{l}\text { Child Behavior } \\
\text { Checklist (parent } \\
\text { report; Achenbach \& } \\
\text { Edelbrock, 1983); } \\
\text { Vineland Social } \\
\text { Maturity Scale (Luer, } \\
\text { Cohen, \& Nauck, } \\
\text { 1972) }\end{array}$ & $\begin{array}{l}\text { Individuals with WS } \\
\text { displayed similar levels of } \\
\text { anxiety as age- and IQ- } \\
\text { matched individuals with } \\
\text { ID. }\end{array}$ \\
\hline
\end{tabular}




\begin{tabular}{|c|c|c|c|c|}
\hline Author(s) & $n$ & Age Range & Measures & Key Findings \\
\hline $\begin{array}{l}\text { Gosch \& } \\
\text { Pankau } \\
(1997)\end{array}$ & 105 & $\begin{array}{l}27 \text { months- } \\
35 \text { years }\end{array}$ & $\begin{array}{l}\text { Child Behavior } \\
\text { Checklist (parent } \\
\text { report; Achenbach \& } \\
\text { Edelbrock, 1983); } \\
\text { adapted version of } \\
\text { Adjective Word List; } \\
\text { parent interview }\end{array}$ & $\begin{array}{l}27 \% \text { of individuals with WS } \\
\text { were identified as having } \\
\text { anxiety problems. }\end{array}$ \\
\hline $\begin{array}{l}\text { Graham, } \\
\text { Rosner, } \\
\text { Dykens, \& } \\
\text { Visootsak } \\
(2005)\end{array}$ & 16 & 5-31 years & $\begin{array}{l}\text { Child Behavior } \\
\text { Checklist (Achenbach, } \\
\text { 1991); Reiss Profiles } \\
\text { of Fundamental Goals } \\
\text { and Motivation } \\
\text { Sensitivities for } \\
\text { Persons with Mental } \\
\text { Retardation (parent } \\
\text { report; Reiss \& } \\
\text { Havercamp, 1998) }\end{array}$ & $\begin{array}{l}\text { Anxiety level was not } \\
\text { significantly different for } \\
\text { individuals with WS } \\
\text { compared to CA-matched } \\
\text { individuals with Down } \\
\text { syndrome, Prader-Willi } \\
\text { syndrome, or CHARGE } \\
\text { syndrome. }\end{array}$ \\
\hline $\begin{array}{l}\text { Kennedy, } \\
\text { Kaye, \& } \\
\text { Sadler } \\
(2006)\end{array}$ & 21 & $7-28$ years & $\begin{array}{l}\text { Anxiety Disorders } \\
\text { Interview Schedule for } \\
\text { DSM-IV Child and } \\
\text { Parent Versions } \\
\text { (Silverman \& Albano, } \\
\text { 1996) }\end{array}$ & $\begin{array}{l}\text { (1) } 48 \% \text { of individuals with } \\
\text { WS met diagnostic criteria } \\
\text { for an anxiety disorder } \\
\text { (specific phobia: } 43 \% \text {, } \\
\text { generalized anxiety } \\
\text { disorder: } 24 \% \text {, panic } \\
\text { disorder: } 5 \% \text {, agoraphobia: } \\
5 \% \text {, post-traumatic stress } \\
\text { disorder: } 5 \% \text { ). } \\
\text { (2) No significant } \\
\text { association between anxiety } \\
\text { disorders in individuals } \\
\text { with WS and family history } \\
\text { of anxiety. }\end{array}$ \\
\hline
\end{tabular}




\begin{tabular}{|c|c|c|c|c|}
\hline Author(s) & $n$ & Age Range & Measures & Key Findings \\
\hline $\begin{array}{l}\text { Leyfer, } \\
\text { Woodruff- } \\
\text { Borden, } \\
\text { Klein- } \\
\text { Tasman, } \\
\text { Fricke, \& } \\
\text { Mervis } \\
(2006)\end{array}$ & 119 & $4-16$ years & $\begin{array}{l}\text { Anxiety Disorders } \\
\text { Interview Schedule for } \\
\text { DSM-IV Parent } \\
\text { Version (Silverman \& } \\
\text { Albano, 1996) }\end{array}$ & $\begin{array}{l}53.8 \% \text { of individuals with } \\
\text { WS met diagnostic criteria } \\
\text { for specific phobia; } 11.8 \% \\
\text { for generalized anxiety } \\
\text { disorder; } 6.7 \% \text { for } \\
\text { separation anxiety; } 2.5 \% \text { for } \\
\text { obsessive-compulsive } \\
\text { disorder; } 1.7 \% \text { for social } \\
\text { phobia; } 0.8 \% \text { for panic } \\
\text { disorder; } 0.8 \% \text { for post- } \\
\text { traumatic stress disorder. }\end{array}$ \\
\hline $\begin{array}{l}\text { Leyfer, } \\
\text { Woodruff- } \\
\text { Borden, \& } \\
\text { Mervis } \\
(2009)\end{array}$ & 132 & $4-16$ years & $\begin{array}{l}\text { Anxiety Disorders } \\
\text { Interview Schedule for } \\
\text { DSM-IV Parent } \\
\text { Version (Silverman \& } \\
\text { Albano, 1996) }\end{array}$ & $\begin{array}{l}\text { (1) } 62.1 \% \text { of individuals } \\
\text { with WS met criteria for an } \\
\text { anxiety disorder (specific } \\
\text { phobia: } 56.1 \% \text {, generalized } \\
\text { anxiety disorder: } 10 \% \text {, } \\
\text { separation anxiety disorder: } \\
8 \% \text { ). } \\
\text { (2) Rates of generalized } \\
\text { anxiety disorder, separation } \\
\text { anxiety disorder, and } \\
\text { specific phobia were } \\
\text { significantly higher for } \\
\text { children with WS than } \\
\text { prevalence rates for TD } \\
\text { children and children with } \\
\text { ID of mixed etiology. }\end{array}$ \\
\hline $\begin{array}{l}\text { Papaeliou et } \\
\text { al. (2011) }\end{array}$ & 20 & $\begin{array}{l}\text { Mean age } \\
5.13 \text { years } \\
\text { (no range } \\
\text { reported) }\end{array}$ & $\begin{array}{l}\text { Child Behavior } \\
\text { Checklist/1.5-5 } \\
\text { (Achenbach \& } \\
\text { Rescorla, 2000) }\end{array}$ & $\begin{array}{l}\text { Individuals with WS scored } \\
\text { significantly higher on } \\
\text { anxiety/depression scale } \\
\text { than TD children matched } \\
\text { for MA, and MA- and CA- } \\
\text { matched children with } \\
\text { Down syndrome. }\end{array}$ \\
\hline
\end{tabular}




\begin{tabular}{|c|c|c|c|c|}
\hline Author(s) & $n$ & Age Range & Measures & Key Findings \\
\hline $\begin{array}{l}\text { Perez- } \\
\text { Garcia, } \\
\text { Granero, } \\
\text { Gallastegui, } \\
\text { Perez- } \\
\text { Jurado, \& } \\
\text { Brun-Gasca } \\
(2011)\end{array}$ & 25 & 5-27 years & $\begin{array}{l}\text { Child Behavior } \\
\text { Checklist (Achenbach, } \\
\text { 1991) }\end{array}$ & $\begin{array}{l}\text { (1) } 72 \% \text { of individuals with } \\
\text { WS scored in the clinical } \\
\text { range on the } \\
\text { anxiety/depression scale. } \\
\text { (2) Anxiety/depression } \\
\text { scores were not associated } \\
\text { with IQ for individuals with } \\
\text { WS. } \\
\text { (3) Individuals with WS } \\
\text { displayed similar levels of } \\
\text { anxiety/depression as } \\
\text { similarly-aged individuals } \\
\text { with Fragile X and ID of } \\
\text { mixed etiology. }\end{array}$ \\
\hline $\begin{array}{l}\text { Porter, } \\
\text { Dodd, \& } \\
\text { Cairns } \\
(2009)\end{array}$ & 31 & $6-48$ years & $\begin{array}{l}\text { Child Behavior } \\
\text { Checklist (parent- } \\
\text { report; Achenbach \& } \\
\text { Rescorla, 2001) }\end{array}$ & $\begin{array}{l}\text { (1) Individuals with WS } \\
\text { displayed high levels of } \\
\text { anxiety. } \\
\text { (2) Negative relation } \\
\text { between visual spatial age- } \\
\text { equivalent and level of } \\
\text { anxiety. }\end{array}$ \\
\hline $\begin{array}{l}\text { Rodgers, } \\
\text { Riby, Janes, } \\
\text { Connolly, \& } \\
\text { McConachie } \\
\text { (2012) }\end{array}$ & 20 & $6-15$ years & $\begin{array}{l}\text { The Spence Children's } \\
\text { Anxiety Scale (Spence, } \\
\text { 1998); Repetitive } \\
\text { Behaviours } \\
\text { Questionnaire (Turner, } \\
\text { 1999) }\end{array}$ & $\begin{array}{l}\text { (1) Individuals with WS } \\
\text { displayed significantly } \\
\text { lower levels of separation } \\
\text { anxiety, social anxiety, and } \\
\text { obsessive-compulsive } \\
\text { disorder than similarly-aged } \\
\text { individuals with autism } \\
\text { spectrum disorder. } \\
\text { (2) Individuals with WS } \\
\text { displayed similar levels of } \\
\text { physical injury fears and } \\
\text { generalized anxiety as } \\
\text { individuals with autism } \\
\text { spectrum disorder. } \\
\text { (3) No association between } \\
\text { repetitive behaviors and } \\
\text { anxiety was found for } \\
\text { individuals with WS. }\end{array}$ \\
\hline
\end{tabular}




\begin{tabular}{|c|c|c|c|c|}
\hline Author(s) & $n$ & Age Range & Measures & Key Findings \\
\hline $\begin{array}{l}\text { Stinson, } \\
\text { Elison \& } \\
\text { Howlin } \\
(2010)\end{array}$ & 85 & $19-55$ years & $\begin{array}{l}\text { Psychiatric } \\
\text { Assessment Schedule } \\
\text { for Adults with } \\
\text { Developmental } \\
\text { Disabilities (Moss, } \\
\text { Prosser, Ibbotson, \& } \\
\text { Goldberg, 1996) }\end{array}$ & $\begin{array}{l}45 \% \text { of individuals with WS } \\
\text { reported anxiety problems, } \\
\text { with } 16 \% \text { meeting criteria } \\
\text { for an anxiety disorder. }\end{array}$ \\
\hline $\begin{array}{l}\text { Stinson, } \\
\text { Tomlinson, } \\
\text { \& Estes } \\
(2012)\end{array}$ & 19 & $20-42$ years & $\begin{array}{l}\text { Psychiatric } \\
\text { Assessment Schedule } \\
\text { for Adults with } \\
\text { Developmental } \\
\text { Disabilities (Moss, } \\
\text { Prosser, Ibbotson, \& } \\
\text { Goldberg, 1996) }\end{array}$ & $\begin{array}{l}\text { (1) Individuals with WS } \\
\text { reported significantly more } \\
\text { anxiety symptoms than } \\
\text { depression symptoms. } \\
\text { (2) Individuals with WS } \\
\text { responded significantly } \\
\text { more slowly to anxiety- } \\
\text { related words than } \\
\text { depression-related words on } \\
\text { an emotional Stroop task. }\end{array}$ \\
\hline $\begin{array}{l}\text { Udwin, } \\
\text { Yule, \& } \\
\text { Martin } \\
(1987)\end{array}$ & 44 & $6-16$ years & $\begin{array}{l}\text { Rutter Questionnaires } \\
\text { (teacher and parent } \\
\text { reports; Rutter, 1967; } \\
\text { Rutter Tizard, \& } \\
\text { Whitmore, 1970 ) }\end{array}$ & $\begin{array}{l}26 \% \text { and } 39 \% \text { of children } \\
\text { with WS were rated as } \\
\text { having anxiety problems by } \\
\text { teachers and parents, } \\
\text { respectively. }\end{array}$ \\
\hline $\begin{array}{l}\text { Udwin } \\
\text { (1990) }\end{array}$ & 119 & $16-38$ years & $\begin{array}{l}\text { Unstandardized } \\
\text { caregiver } \\
\text { questionnaire, with } \\
\text { some items adapted } \\
\text { from Rutter Parent } \\
\text { Questionnaire (Rutter } \\
\text { et al., 1970) }\end{array}$ & $\begin{array}{l}87 \% \text { of individuals with WS } \\
\text { reported difficulties with } \\
\text { worry, and } 73 \% \text { described } \\
\text { as fearful. }\end{array}$ \\
\hline $\begin{array}{l}\text { Udwin \& } \\
\text { Yule (1991) }\end{array}$ & 20 & $6-14$ years & $\begin{array}{l}\text { Rutter Questionnaires } \\
\text { (teacher and parent } \\
\text { reports; Rutter, 1967; } \\
\text { Rutter et al., 1970) }\end{array}$ & $\begin{array}{l}\text { Children with WS } \\
\text { demonstrated significantly } \\
\text { more fear than children } \\
\text { matched for CA- and verbal } \\
\text { IQ who had similar levels } \\
\text { of anxiety. }\end{array}$ \\
\hline
\end{tabular}




\begin{tabular}{|c|c|c|c|c|}
\hline Author(s) & $n$ & Age Range & Measures & Key Findings \\
\hline $\begin{array}{l}\text { Woodruff- } \\
\text { Borden, } \\
\text { Kistler, } \\
\text { Henderson, } \\
\text { Crawford, \& } \\
\text { Mervis } \\
(2010)\end{array}$ & 45 & 4-16 years & $\begin{array}{l}\text { Anxiety Disorders } \\
\text { Interview Schedule for } \\
\text { DSM-IV Parent } \\
\text { Version (Silverman \& } \\
\text { Albano, 1996) }\end{array}$ & $\begin{array}{l}\text { Over the course of } 3 \text { or } \\
\text { more interviews separated } \\
\text { by at least } 1 \text { year, } 82.2 \% \text { of } \\
\text { children with WS met } \\
\text { diagnostic criteria for an } \\
\text { anxiety disorder, with } \\
62.2 \% \text { having a chronic } \\
\text { course. }\end{array}$ \\
\hline $\begin{array}{l}\text { Zarchi et al. } \\
\text { (in press) }\end{array}$ & 24 & $\begin{array}{l}\text { Mean age } \\
16.8 \text { years } \\
\text { (no range } \\
\text { reported) }\end{array}$ & $\begin{array}{l}\text { Schedule for Affective } \\
\text { Disorders and } \\
\text { Schizophrenia for } \\
\text { School-Age Children- } \\
\text { Present \& Lifetime } \\
\text { Version (Kaufman et } \\
\text { al., 1997); Structural } \\
\text { Clinical Interview for } \\
\text { DSM-IV Axis I } \\
\text { Disorders Research } \\
\text { Version (First, Gibbon, } \\
\text { Spritzer, Williams, \& } \\
\text { Benjamin, 1996) }\end{array}$ & $\begin{array}{l}\text { (1) } 50 \% \text { of individuals with } \\
\text { WS met criteria for an } \\
\text { anxiety disorder: specific } \\
\text { phobia: } 45.8 \% \text {, separation } \\
\text { anxiety disorder: } 12.5 \% \text {, } \\
\text { generalized anxiety } \\
\text { disorder: } 8.3 \% \text {, obsessive- } \\
\text { compulsive disorder: } 4.2 \% \text {, } \\
\text { post-traumatic stress } \\
\text { disorder: } 4.2 \% \text {. } \\
\text { (2) Individuals with WS had } \\
\text { significantly higher rates of } \\
\text { specific phobia than did } \\
\text { individuals with ID } \\
\text { matched on CA and IQ. }\end{array}$ \\
\hline
\end{tabular}

Note. $\mathrm{WS}=$ Williams syndrome; ID = intellectual disability; $\mathrm{TD}=$ typically developing.

Several studies have reported diagnostic information for anxiety disorders in WS based on findings from clinical interviews. Results from both parent- and child-report clinical interviews indicated increased prevalence rates of specific phobia and overanxious/generalized anxiety disorder compared to both TD children and groups with ID of various etiologies (Cherniske et al., 2004; Dodd \& Porter, 2011a; Dodd \& Porter 2011b; Dodd et al., 2009; Dykens, 2003; Kennedy et al., 2006; Leyfer et al., 2006; Leyfer et al., 2009; Woodruff-Borden et al., 2010; Zarchi et al., in press). In line with reports of increased fearfulness to loud noise, the most prevalent phobia reported in the WS 
literature is of loud noise (Leyfer et al., 2006). Results of a longitudinal study of anxiety in children with WS based on clinical interviews indicated that over a 5-year period, $82 \%$ of children met DSM-IV criteria for an anxiety disorder at some point, and $62 \%$ maintained a chronic course (Woodruff-Borden et al., 2010).

Limitations to this literature include the use of small sample sizes and/or broad age ranges, the use of assessment tools which have not been validated for individuals with cognitive impairments, relying on caregiver- rather than self-reports of problems, failing to assess for clinical impairment or severity, and using child measures when assessing adults. However, given the challenges of acquiescence bias and adequate reporting in children with ID (Heal \& Sigelman, 1995) parent-report appears to be the most valid means for assessment of problem behaviors. Overall, the extant literature on anxiety in WS provides a good body of descriptive information regarding increased prevalence and impairment.

Further support of the genetic risk associated with anxiety conferred by one or more genes in the WS region is provided by data collected on individuals with $7 \mathrm{q} 11.23$ duplication syndrome. Recent prevalence estimates of DSM-IV anxiety disorders in children with 7q11.23 duplication syndrome are: specific phobia: 50\%, separation anxiety: $15.4 \%$, social phobia: $50 \%$, selective mutism: $23.1 \%$, generalized anxiety disorder: 7.7\%, obsessive-compulsive disorder: 3.8\% (Henderson et al., 2014). In addition, Mervis et al. (2012) conducted a study examining separation anxiety in children with 7q11.23 duplication syndrome and mouse pups with duplication of Gtf2i, the most telomeric gene in the WS region. Rates of separation anxiety disorder in children with 7q11.23 duplication syndrome were significantly higher than found in the general 
population, and mouse pups with duplication of Gtf2i demonstrated increased levels of separation anxiety as measured through ultrasonic vocalizations when separated from their mothers. Taken together, these findings point toward the influence of genes in the WS region on chromosome $7 \mathrm{q} 11.23$ on the increased probability of experiencing anxiety symptoms and/or anxiety disorders.

The existence of anxiety as a behavioral concern in WS is evident. However, despite over 20 years of research on anxiety in this population, little is known about why these individuals are at an increased risk. Studies of knock-out mice and children with duplication of the WS region confirm the genetic risk for experiencing increased levels of anxiety. Additionally, as indicated in Table 1, the results of several studies indicate that individuals with WS are at a higher risk of experiencing anxiety problems relative to individuals with ID of a variety of other etiologies (Dykens, 2003; Dykens \& Rosner, 1999; Einfeld et al., 1997; Einfeld et al., 2001; Udwin \& Yule, 1991). These findings further underscore the necessity to investigate association factors with anxiety in individuals with WS.

A small body of literature has examined associations between anxiety and other characteristics of the behavioral phenotype of WS. For example, a few studies have examined the potential relation between intellectual ability and anxiety, with no significant associations found (Dodd \& Porter, 2011a; Gagliardi et al., 2011; Leyfer et al., 2006; Leyfer et al., 2009; Perez-Garcia et al., 2011; Porter et al., 2009). In a study on sensory modulation in WS, John and Mervis (2010) used cluster analysis to identify two clusters of children with WS (low sensory-modulation impairment, high sensorymodulation impairment) and examined differences in other domains of functioning as a 
function of cluster. Scores for domains associated with internalizing problems such as negativity and anxiety and with attention-related complications were found to be significantly worse for the high-sensory impairment cluster. In a study of the longitudinal course of anxiety in children with WS, Woodruff-Borden et al. (2010) found an association between self-regulation problems and anxiety. Similarly, Leyfer et al. (2012) found that lower scores on temperament subscales of attentional focusing and inhibitory control were associated with anxiety disorders in children with WS aged 5-10 years. Taken together, the findings of these studies suggest that the behavioral phenotype features of sensory modulation difficulties, poor self-regulation abilities, and temperament aspects of negative reactivity may share an important association with anxiety in children with WS.

In regard to investigating risk factors for psychopathology in genetic syndromes, Dykens (1999) proposed that researchers examine the risks that the syndrome's genotype provides (direct effects) as well as the role the resulting phenotype factors play in influencing person-environment transactions (indirect effects). In this view, it is important to attempt to understand genetic versus psychosocial risk factors that may play a role in the etiology and maintenance of psychiatric disorders. A specific focus is made on understanding how characteristics of a genetic phenotype predispose and influence the experience of anxiety. Crnic, Hoffman, Gaze, and Edelbrock (2004) suggest a similar view, discussing the importance of investigating both factors that are endogenous or representative of the child and the developmental disability/syndrome itself as well as those factors which are exogenous or are characteristic of external influences, such as increased parenting stress and limited social support. Both Crnic et al. (2004) and 
Dykens (1999) encourage researchers in the dual diagnosis field to look beyond descriptive information regarding the psychiatric symptoms and use information about the genetic syndrome to better understand etiology and function.

In a seminal paper on developmental psychopathology, Morton and Frith (1995) proposed a structural framework to facilitate the conceptualization and exploration of psychiatric disorders. The authors suggest this framework as a means for beginning empirical exploration of causal models and emphasize the importance of making adjustments and re-conceptualizations as research findings accrue. In this framework, a psychiatric disorder may be conceptualized as existing in a hierarchical causal system with multiple levels (typically 3 levels; see Figure 1). The first level constitutes the biological origins of a disorder or its underlying cause, with a direct causal pathway leading to the second level, which represents functional impairments or consequences, such as brain changes. Applied to individuals with WS, level 1 can be understood as the genetic deletion of 7q11.23, which results in neurobiological changes and characteristic phenotypic features such as heightened negative reactivity, poor self-regulation, and sensory modulation difficulties. The impairments/consequences of the second level have pathways that lead to the final level, which encompasses anxiety symptoms, represented at level 3. Additional general influences that are not directly related to the origin are also considered and may have an impact at all levels. Examples of outside influences may include environmental factors such as stressful life events or parenting practices. The authors term these pathways "chains of circumstance" (p. 373) and explain that in this framework causality is understood but not directly stated. Using this framework, when two events, such as event $x$ (e.g., sensory modulation difficulties) and event $y$ (e.g., 
anxiety symptoms), are linked, there becomes an increased probability of $y$ occurring where $x$ is observed. This allows for the variability seen at the second level. The influence of outside factors or events may also be accounted for, although addressing this component of the model is not within the scope of the present study so is not included in Figure 1. Both Crnic et al.'s (2004) and Dykens' (1999) views of endogenous/exogenous factors and direct/indirect effects fit well into the framework suggested by Morton and Frith (1995).

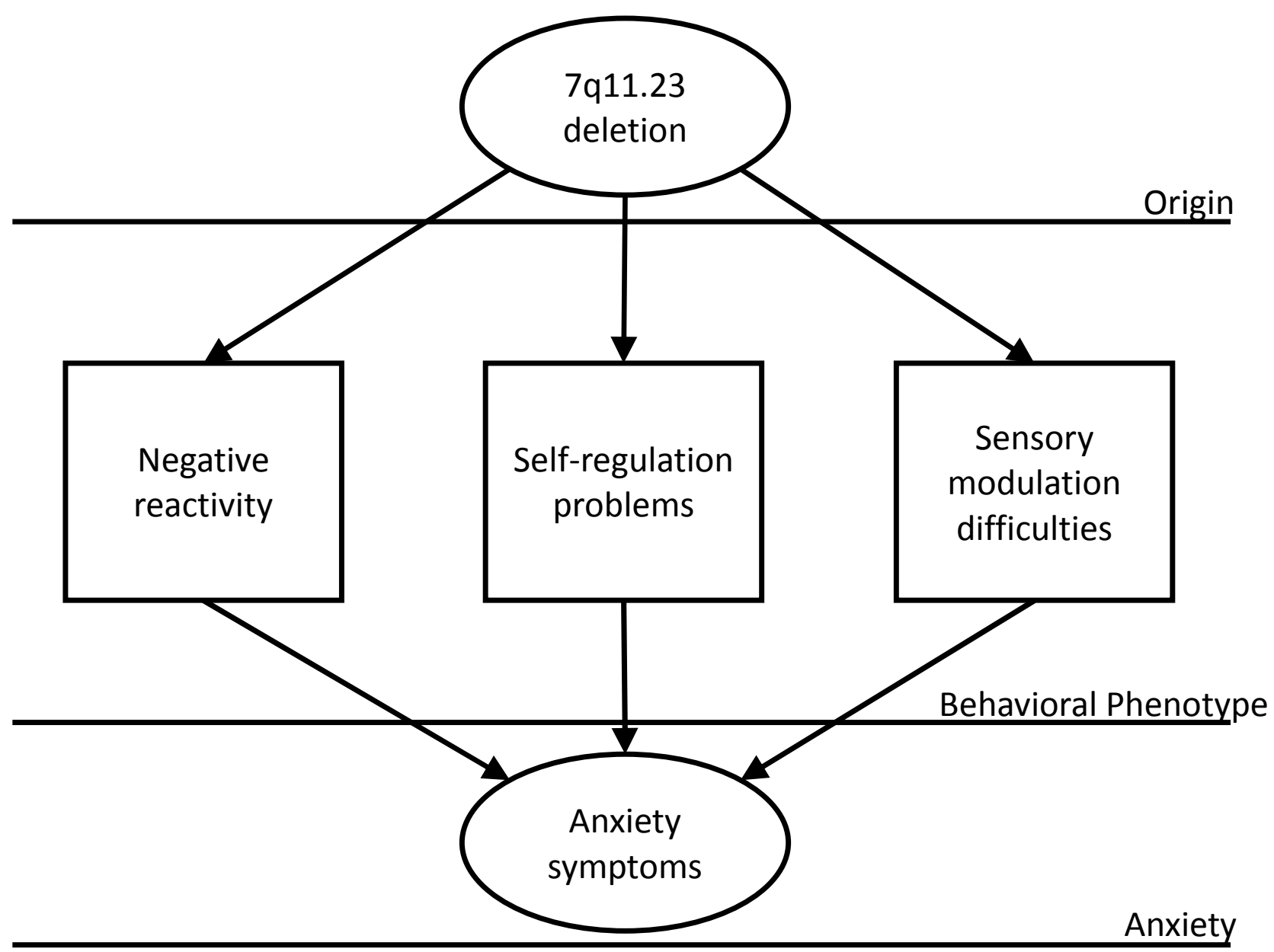

Figure 1. Schematic depiction of structural framework for conceptualizing psychiatric symptoms/disorders. 
Using these ideas within this framework provides an excellent starting point for furthering the understanding of anxiety in WS (see Figure 1). In the next section I examine additional literature that supports links between characteristics that are found in the WS behavioral phenotype and anxiety in children. Specifically, neurobiological findings, negative reactivity, self-regulation problems, and sensory processing difficulties are considered.

\section{Williams Syndrome Phenotype}

Neurobiological Findings. Structural and functional abnormalities in the brain have been found in individuals with WS. Specifically, increased neural reactivity in the amygdala combined with decreased reactivity in orbitofrontal cortex (OFC) regions may predispose individuals with WS to experience increased levels of anxiety. MeyerLindenberg et al. (2004) found reduced gray matter in the OFC in a sample of highfunctioning individuals with WS. Further, high-functioning individuals with WS have been found to demonstrate hyperactivation of the amygdala to threatening nonsocial stimuli (with reduced activation to threatening social stimuli), without recruitment of the OFC region (Meyer-Lindenberg et al., 2005). The authors suggest that these results may point toward a primary OFC deficit, with functional disconnection from the amygdala, and may serve to explain at least partially some of the increased levels of nonsocial anxiety observed in individuals with WS. Specifically, decreased functionality in the regulatory abilities of the OFC to modulate limbic system arousal may influence the experience of anxiety for individuals with WS.

The OFC has been functionally associated with fear extinction and inhibition of excessive fear/anxiety responses (Milad \& Rauch, 2007). It has been hypothesized that 
hyperactivation of the amygdala in conjunction with OFC dysfunction may increase a person's likelihood of experiencing anxiety, specifically in regard to phobias (Milad \& Rauch, 2007). Information from sensory cortices is conveyed directly to the OFC and the amygdala via neural projections for further processing. The amygdala has been functionally associated with basic motivational tendencies and facilitates approachavoidance behavior through reactivity of the autonomic nervous system (Iversen, Kupfermann, \& Kandel, 2000). This reactivity/arousal activates the "fight or flight" system and prepares the body for future behavior that may facilitate survival (such as increased heart rate, narrowing of attention, sweating). Information coming from sensory modalities can provide the necessary reactivity and arousal for rapid behavioral responses through amygdala activation. The OFC primarily serves a regulatory function through its association with executive functions such as behavioral and emotional inhibition, decision-making, and flexible responding (Kringelbach \& Rolls, 2004). Receiving projections from the sensory cortices and projecting to the amygdala through bidirectional connections, the OFC has a unique capability to evaluate information from the environment as well as modulate neural reactivity from the amygdala. A schematic drawing is presented below to further depict the neural circuitry associated with the OFC and amygdala (Figure 2). 


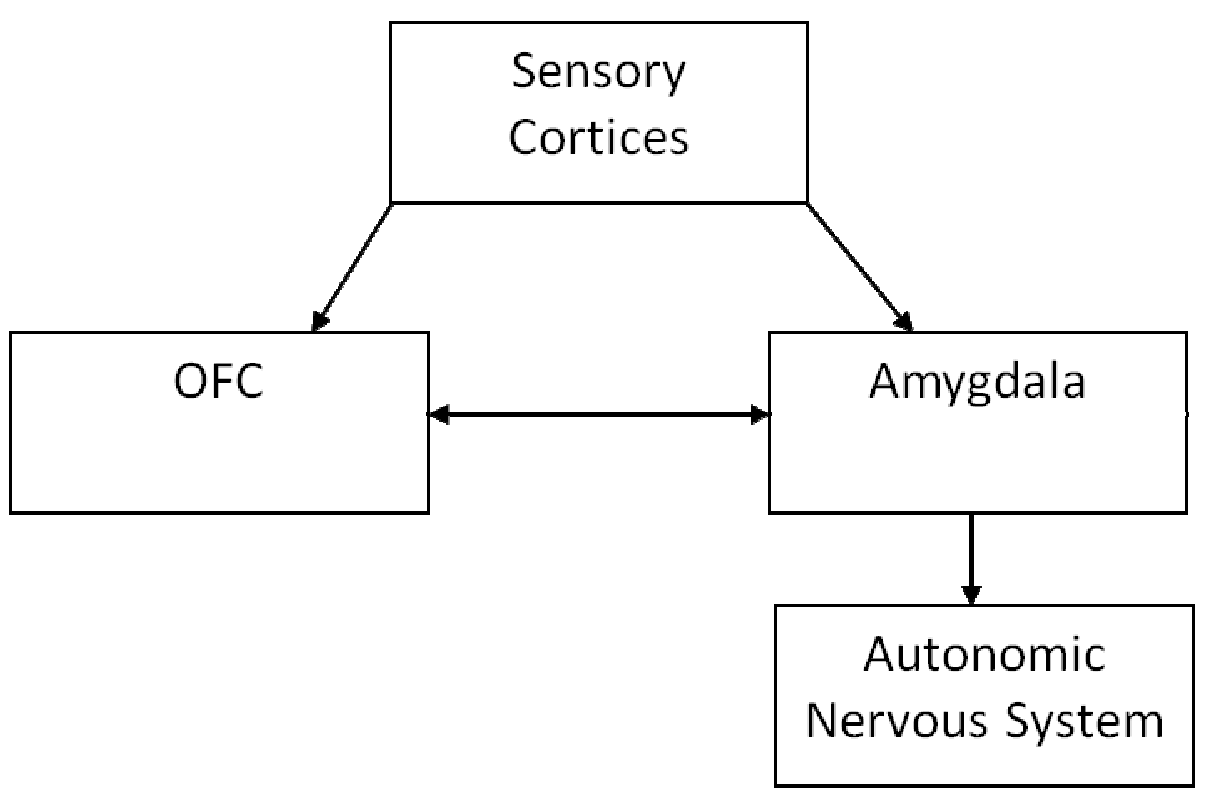

Figure 2. OFC-limbic system neural circuitry.

As seen in Figure 2, information from sensory channels can be sent directly to the amygdala, which may result in neural reactivity and autonomic arousal. The hyperactivation of the amygdala to nonsocial stimuli observed in WS may create excessive neural reactivity, leading to heightened emotional arousal in the absence of true threat. Further, the self-regulation of this arousal may not be adequately modulated through connections with the OFC, in line with the functional deactivation of this connection found in WS (Meyer-Lindenberg et al., 2005). Therefore, heightened levels of reactivity coupled with decreased regulatory function within the neural circuitry of individuals with WS may predispose them to experience chronic levels of anxiety. Behaviorally, patterns of emotional reactivity, poor self-regulation, and sensorymodulation difficulties have all been associated with the WS phenotype. In the next section I review these aspects of the WS behavioral phenotype and examine associations with anxiety found in the literature on TD children and children with autism. 
Negative Reactivity. Temperament is defined as "constitutionally based individual differences in reactivity and self-regulation, as seen in the emotional, motor, and attentional domains" (Rothbart, Ellis \& Posner, 2004, p. 356). Negative reactivity refers to the amount of negative affect experienced through discomfort, anger/frustration, fear, and sadness, as well as difficulty recovering from peak levels of distress, excitement, or arousal (Rothbart et al., 2001). Biologically, negative reactivity has been associated with the neuroanatomical substrates of the amygdala, prefrontal cortex (PFC), hippocampus, and the anterior cingulate cortex (Whittle, Allen, Lubman, \& Yucel, 2006). One of the most commonly documented aspects of the WS phenotype is a characteristic personality. Studies of personality/temperament have found that individuals with WS demonstrate high levels of empathy, gregariousness, visibility, intensity, sadness, tenseness, sensitivity, negative mood, distractibility, anxiousness, tearfulness, agreeableness, and curiosity (e.g., Gosch \& Pankau, 1997; Klein-Tasman \& Mervis, 2003; Tomc et al., 1990). In addition, individuals with WS have been shown to demonstrate a low threshold of excitability and low conscientiousness (Klein-Tasman \& Mervis, 2003; van Lieshout, De Meyer, Curfs, \& Fryns, 1998). Taken together, the results of these studies suggest that individuals with WS are social and empathic but exhibit a strong undercurrent of negative reactivity.

Klein-Tasman and Mervis (2003) conducted a discriminant analysis of personality and temperament traits between 8 - 10-year-olds with WS and a CA- and IQ-matched group of children with ID of mixed etiology using the Children's Behavior Questionnaire (CBQ; Rothbart \& Ahadi, 1994) and the Multidimensional Personality Questionnaire (MPQ; Tellegen, 1985). Results indicated that 21 of the 22 children with WS were 
correctly classified by high levels of the temperament traits of empathy, approach, and shyness (reversed) and of the personality traits of gregariousness, people-oriented, tenseness, sensitivity, and visibility, whereas only 3 of 20 participants in the mixedetiology group fit these patterns. That is, sensitivity was found to be .96 and specificity was found to be .85 for both the profile based on the CBQ and the profile based on the MPQ. Results from this study demonstrate that individuals with WS generally can be characterized by personality and temperament traits that are reflective of sociability and negative reactivity.

van Lieshout et al. (1998) investigated personality in a group of children and adolescents with WS aged 2-19 years and compared the results to control groups of individuals with Prader-Willi syndrome, individuals with Fragile X syndrome, and TD children. Parents rated personality characteristics using the California Child Q-set (Block \& Block, 1980), which includes the following scales: extraversion-introversion, agreeableness, conscientiousness, emotional stability, openness, motor activity, and irritability/immaturity. The WS group scored significantly lower than the TD controls on emotional stability, agreeableness, motor activity, and openness, and higher on irritability. The WS group scored significantly higher than both the Prader-Willi syndrome group and the Fragile $\mathrm{X}$ syndrome group on agreeableness and lower than the Prader-Willi syndrome group on conscientiousness. Similarly, in a study of personality in a group of children with WS (Udwin \& Yule, 1991) utilizing the Rutter Questionnaires (Rutter, 1967; Rutter, Tizard, \& Whitmore, 1970), teachers rated children with WS as more fearful, fussy, and more likely to have twitches or mannerisms than TD children, 
and parents rated children with WS as having more twitches, being more solitary, and demonstrating less concentration than TD children.

To date, only one study has examined the relation between temperament and anxiety disorders in children with WS. Leyfer et al. (2012) found that scores on a temperament factor comprised of CBQ subscales measuring fear, discomfort, positive anticipation (reversed), and perceptual sensitivity were significantly higher for children with WS who had an anxiety disorder than for children with WS who did not.

Difficult temperament characterized by negative reactivity has been shown to be associated with anxiety in children in the general population. Difficult/negative temperament is described as the "presence of negative emotionality coupled with reports that the child's behavior is hard to manage" (Perez-Edgar \& Fox, 2005, p. 685). Lonigan, Carey, and Finch (1994) found that children diagnosed with anxiety disorders from a clinical inpatient sample also exhibited high levels of negative affectivity. Similarly, Lonigan, Phillip, and Hooe (2003) found that children who had high self-report ratings of negative reactivity were more likely to exhibit anxiety symptoms both concurrently and seven months later. Further, changes in anxiety symptoms across time points were associated with changes in negative affect but not positive affect.

Findings from twin studies have indicated that negative reactivity has a strong genetic component and serves as a risk factor for behavior difficulties (Gjone \& Stevenson, 1997). Longitudinal studies have found that children with difficult temperaments during early childhood are at increased risk for developing an anxiety disorder. In a longitudinal study of temperament and behavior problems, Rende (1993) found that the parent-rated temperamental trait of emotionality at ages $1-4$ years was 
significantly associated with and predicted anxiety/depression at age 7 years. Similarly, Craske, Poulton, Tsao, and Poulton (2001) found that temperament aspects of negative reactivity assessed at age 3 years through behavioral observations (measuring emotional reactivity, fearfulness, shyness, and separation anxiety) were associated with Agoraphobia/Panic Disorder at age $18-21$ years. Grant, Bagnell, Chambers, and Stewart (2009) found that difficult temperament at age $2-3$ years was associated with caregiver-reported anxiety symptoms at ages $6-7$ and $8-9$ years, while fearful distress at age $2-3$ years was associated with caregiver-reported anxiety at age $8-9$ years. In addition, difficult temperament at age $2-3$ years predicted caregiver-report anxiety at ages $6-7$ and $8-9$ years. Fearful distress at age $2-3$ years also predicted caregiverreported anxiety at $8-9$ years. Similarly, in a longitudinal prospective study Mian, Wainwright, Briggs-Gowan, and Carter (2011) found that parent-rated child factors at age 3 years, including negative emotionality, predicted parent-rated anxiety symptoms at age 6 years and child-rated anxiety symptoms at age 8 years.

Taken together, the findings from the child personality/temperament literature suggest that level of negative reactivity is related to level of anxiety. Children with clinical levels of anxiety have been shown to exhibit more difficult temperaments. Further support for the role of negative reactivity in anxiety is demonstrated in studies that show that high ratings of emotionality and fearfulness precede and predict anxiety symptoms later in life. This is true both during childhood and into adulthood. Overall, negative reactivity appears to be a risk factor for the development of anxiety in children.

One major limitation to the literature just reviewed is the use of subjective measures of temperament/personality, primarily by parent-report. However, similar 
results have been found through objective measures of temperament (Craske et al., 2001). In addition, studies using both subjective ratings and clinical interviews of anxiety have found similar results regarding the relation between negative reactivity and anxiety. As previously mentioned, studies of personality in WS have found patterns of intensity, sadness, tenseness, sensitivity, negative mood, anxiousness, and tearfulness. In addition, aspects of negative reactivity such as discomfort and fear have been associated with anxiety disorders in children with WS. These results, taken together with findings from the TD literature, provide strong support for an association between anxiety symptoms and negative reactivity in WS.

Self-regulation Problems. Self-regulation is defined as "processes that serve to modulate reactivity, including fearful inhibition, surgent or extraverted approach, and the effortful control of behavior based on the executive attention system" (Rothbart et al., 2004, p. 358). Self-regulation has been associated with the neurobiological substrates of the OFC, the dorsolateral prefrontal cortex, and the anterior cingulate cortex (Whittle et al., 2006). Difficulties with self-regulation, such as poor inhibition, poor adaptability, perseveration, and hyperactivity, have been documented as weaknesses for individuals with WS (Arnold et al., 1985; Davies et al., 1998; Dilts et al., 1990; Dykens \& Rosner, 1999; Gosch \& Pankau, 1994; Klein-Tasman \& Mervis, 2003; Tomc et al., 1990; Udwin, 1990; Udwin et al., 1998; Udwin \& Yule, 1991; Udwin, Yule, \& Martin, 1987). Further, executive functioning abilities have been associated with anxiety, problem behaviors, and sensory modulation difficulties in children with WS, underscoring the significance of these regulatory skills (John \& Mervis, 2010). 
Woodruff-Borden et al. (2010) used the Behavior Rating Inventory of Executive Functioning (BRIEF; Gioia et al., 2000) to investigate the association between aspects of executive functioning and the probability of having an anxiety disorder in children with WS. The findings from this study showed that decreased levels of self-regulation, measured using the BRIEF Behavior Regulation Index, increased the odds of having an anxiety diagnosis in children with WS. In line with these results, Leyfer et al. (2012) found that scores on a temperament factor comprised of the CBQ attentional focusing and inhibitory control scales were significantly lower for children who had an anxiety diagnosis than for those children who did not.

Other types of difficulties with self-regulatory abilities have also been reported for children with WS. Specifically, studies have shown that individuals with WS have difficulty with inhibitory control as indexed by measures of hyperactivity, approach, and attention seeking behaviors (Arnold et al., 1985; Dilts et al., 1990; Dykens \& Rosner, 1999; Klein-Tasman \& Mervis, 2003; Tomc et al., 1990; Udwin, 1990; Udwin et al., 1998; Udwin \& Yule, 1991). Individuals with WS also have been shown to demonstrate difficulties with set-shifting and emotion regulation, as indexed by measures of low adaptability, high preoccupations, low persistence, high levels of stress reaction, and increased temper tantrums (Davies et al., 1998; Klein-Tasman \& Mervis, 2003; Tomc et al., 1990; Udwin, 1990; Udwin et al., 1987).

Self-regulatory abilities have been shown to be associated with anxiety in TD children. For example, during stress-inducing situations children who score high on measures of effortful control have been found to demonstrate greater emotion-regulation and to employ more adaptive coping strategies than do children who score low on 
measures of effortful control (Derryberry \& Reed, 1996; Eisenberg et al., 1997). In addition, a negative association has been found between overall level of effortful control and anxiety symptoms in children and adolescents (van Oort, Greaves-Lord, Ormel, Verhulst, \& Huizink, 2011). Further, low levels of attentional control have been associated with anxiety symptoms in school-aged children (Muris, de Jong, \& Engelmen, 2004; Verstraeten, Bijttebier, Vasey, \& Raes, 2010), and children with high levels of anxiety and depression symptoms have been shown to have significantly decreased attentional control as compared to children without these problems (Eisenberg et al., 2001).

More recent models have been proposed to examine the association between the factors of reactivity and regulation, with findings suggesting that the combination of high negative reactivity and low self-regulation shares a relation with childhood anxiety problems. Specifically, research findings have shown that high level of emotional reactivity coupled with low self-regulation ability to modulate these responses serves as a risk factor for developing anxiety in childhood (Anthony, Lonigan, Hooe, \& Phillips, 2002; Eisenberg et al., 2001; Lonigan, Vasey, Phillips \& Hazen, 2004; Meesters, Muris, \& van Rooijen, 2007).

Taken together, these findings provide compelling empirical support for an association between difficulty with self-regulation and anxiety problems. In particular, emerging evidence suggests that the interplay of increased negative reactivity with poor self-regulatory skills may play a role in the development and/or maintenance of childhood anxiety. Results from the WS literature also support an association between self-regulation and anxiety. In sum, the empirical findings from both the TD and WS 
literatures warrant further investigation into the association between self-regulation and anxiety in children with WS.

Sensory Modulation Difficulties. Problems in sensory modulation are theorized to be related to abnormally low or abnormally high neuronal thresholds for input of sensory information, resulting in hyper- or hypo-sensitivity to stimuli (Dunn, 1997). Individuals with hypersensitivity often experience sensory defensiveness, which is defined as "hedonically negative behavioral responses indicating withdrawal or protest that appear to be unusual reactions to noxious levels of sensation" (Goldsmith, Van Hulle, Arneson, Schreiber, \& Gernsbacher, 2006, pp. 393-394). Sensory modulation difficulties have been reported by parents of children with WS and anecdotally by researchers studying WS for years. Some of the earliest reports surfaced 20 years ago, with descriptions of exaggerated startle response to sound and anticipatory anxiety related to loud noise (Dilts et al., 1990). Although sensory modulation difficulties have been frequently noted in this population (e.g., Gosch \& Pankau, 1994, 1997; Leyfer et al., 2006; Udwin, 1990; Udwin et al., 1987), there have been few attempts to understand the nature of sensory-related problems. John and Mervis (2010) explored sensory problems in children with WS using the Short Sensory Profile (McIntosh, Miller, Shyu, \& Dunn, 1999). The SSP is a caregiver-report form in which tactile sensitivity, movement sensitivity, taste/smell sensitivity, auditory filtering, visual/auditory sensitivity, low energy/weak, and underresponsive/sensation seeking are assessed. John and Mervis found that $83.4 \%$ of participants exhibited sensory problems, with the greatest difficulty in the auditory filtering, low energy/weak, and under-responsive/seeks sensation domains. In addition, a cluster analysis indicated that the children were best classified 
into two groups, described as high- or low-sensory impairment. The high sensory impairment group demonstrated significantly more difficulties on measures of executive functioning, adaptive functioning, attention-related complications, anxiety, and negative affect/effortful control than did the low sensory impairment group.

Sensory processing abnormalities have been associated with anxiety in both children with ID and TD children. The modulation of sensory input has been conceptualized as existing on three main dimensions: over-responsivity (overly short latencies to respond and/or longer duration of response), under-responsivity (overly long latencies to respond and/or lack of conscious awareness), and seeking (strong desire/interest in sensory sensation which is long in duration/intensity) (Greenspan \& Wieder (2005); Miller, Anzalone, Lane, Cermak, \& Osten, 2007). Sensory overresponsivity can result in central nervous system arousal, which creates a similar fight or flight response as is experienced from anxiety (Lane, 2002).

Goldsmith et al. (2006) investigated the association between sensory sensitivity and internalizing symptoms in a large sample of toddlers included in a twin study, based on caregiver report. Results indicated that sensory defensiveness was related to internalizing symptoms and that having defensiveness in more than one sensory domain further increased this risk. Similarly, Ben-Sasson, Carter, and Briggs-Gowan (2009) found that children aged $9-11$ years with increased levels of sensory over-responsivity displayed higher internalizing problems at age $1-4$ years. Further, Reynolds and Lane (2009) found that levels of anxiety symptoms were significantly higher in a group of TD children with ADHD and sensory over-responsivity compared to a group of TD children with ADHD and no sensory difficulties. 
Results from the autism literature show similar findings. Tsuji et al. (2009) conducted a study investigating the relation between sensory hypersensitivity, anxiety, and depression in a group of children with high-functioning pervasive developmental disorder. Participants were divided into a high sensory-sensitivity and a low sensorysensitivity group. Results indicated that the high sensitivity group had significantly higher levels of internalizing symptoms as compared to the low sensitivity group. In a similar study, Ben-Sasson et al. (2008) found that children generally fell into three clusters of high-, mixed-, and low-frequency of consistent sensory difficulties across domains, and that the high-frequency cluster was differentiated from the low-frequency cluster by increased levels of anxiety. Similarly, Green, Ben-Sasson, Soto, and Carter (2012) found that sensory over-responsivity at age 2 years predicted elevated anxiety symptoms one year later for toddlers with autism spectrum disorder. In addition, Pfeiffer, Kinnealey, Reed, and Herzberg (2005) found that children and adolescents with Asperger syndrome demonstrated a significant positive relation between sensory defensiveness and anxiety symptoms.

In summary, findings from the sensory processing literature suggest a potential association between sensory processing difficulties and child anxiety. In particular, anxiety/internalizing symptoms may differentiate children who exhibit high vs. low levels of sensory sensitivity. Interpretations of this literature must be made carefully, however, as there are few published studies investigating this association.

Auditory sensitivity has been described as a concern in WS, with $28 \%$ of children meeting DSM-IV diagnostic criteria for specific phobia to loud noise (Leyfer et al., 2006). Further, results from a behavioral observation study of young children with WS 
indicated that individuals with WS demonstrate both increased startle responses to auditory stimuli as indexed through eye blinks and anticipatory concern about experiencing noise, as compared to a control group of children with ID matched on CA and IQ (Gallo et al., 2008). Investigations into this sensitivity have uncovered a possible anatomical basis for it, implicating impaired cochlear functioning accompanied by an absence of acoustic reflexes, potentially leading to increased perceived intensity of sounds at certain thresholds and environmentally-induced sensorineural hearing loss (Attias, Raveh, Ben-Naftali, Zarchi \& Gothelf, 2008; Marler, Elfenbein, Ryals, Urban, \& Netzloff, 2005). Further, emerging evidence suggests that sensory sensitivity may extend beyond the auditory domain, with $>50 \%$ of children with WS showing processing abnormalities in the energy and under-responsive/sensation seeking domains (John \& Mervis, 2010). Given the preliminary findings linking sensory defensiveness to anxiety symptoms in children, exploration of this potential link in children with WS is warranted.

\section{Dissertation Project}

While the literature on anxiety in individuals with WS is rich in descriptive information, a clear understanding of associated factors beyond the genotype is needed. An examination of aspects of the neurobiological and behavioral phenotype associated with WS, along with supporting empirical evidence found in the TD child and autism literatures, suggests that negative reactivity, problems with self-regulation, and sensory modulation difficulties may share an association with anxiety in children with WS. Specifically, high levels of negative reactivity and sensory modulation problems, coupled with poor ability to self-regulate these experiences, may increase the frequency and intensity of the experience of anxiety. In this view, the behavioral phenotype aspects of 
negative reactivity, problems with self-regulation, and sensory modulation difficulties may be conceptualized as providing a shared relation with anxiety symptoms in WS.

The hypotheses for this dissertation study are as follows:

1) The shared variance among negative reactivity, sensory modulation difficulties, and self-regulation problems in children with WS is adequately represented by a single underlying 'behavioral phenotype' factor.

2) The shared variance found in the 'behavioral phenotype' factor has a significant relation with anxiety symptoms in children with WS, yielding a medium to large effect size. 


\section{CHAPTER II}

\section{METHODS AND RESULTS}

\section{Methods}

\section{Participants}

Power Analysis. Studies investigating the association between the factors of negative reactivity, self-regulation, sensory modulation problems, and anxiety symptoms in both the TD and the ID literatures have yielded product-moment $r$-values ranging from .40 - .60 (e.g., Green, Ben-Sasson, Soto, \& Carter, 2012; Meesters, Muris, van Rooihen, 2007). In accordance with these findings and Cohen's (1992) guidelines, a significant association between the behavioral phenotype factor and anxiety in children with WS was expected, with a medium to large effect size. A power analysis was conducted using GPower 3 (Faul, Erdfelder, Lang, \& Buchner, 2007) to estimate the minimum sample size required to detect a medium effect size. For a regression analysis with 1 predictor, a sample size of 55 participants is needed to detect a medium effect size with alpha at .05 and power of .80 .

Participant Characteristics. Participants were 115 children (60 females, 55 males) with a genetically confirmed classic WS deletion, aged $6.00-10.97$ years $(M=$ 8.43; $S D=1.59$ ), and their primary caregivers. These data are part of an ongoing study investigating the development of children with WS at the Neurodevelopmental Sciences Laboratory at the University of Louisville (Director: Dr. Carolyn Mervis). Children were 
excluded if they also had an autism spectrum disorder, an additional genetic disorder expected to affect intellectual functioning or behavior, or organic brain damage. The racial and ethnic distribution of the 115 participants was: 88 (76.5\%) White nonHispanic; 7 (6.1\%) White Hispanic; 4 (3.5\%) Asian non-Hispanic; 3 (2.6\%) AfricanAmerican non-Hispanic; 9 (7.8\%) biracial non-Hispanic [3 (2.6\%) American Indian and White; 2 (1.7\%) Asian and White; 1 (0.9\%) African-American and White; 1 (0.9\%) African-American and American-Indian; 1 (0.9\%) African-American and Asian; 1 (0.9\%) Hawaiian/Pacific Islander and White]; 3 (2.6\%) biracial Hispanic [2 (1.7\%) American-Indian and White; 1 (0.9\%) Asian and White]; and 1 (0.9\%) triracial Hispanic (American-Indian, African-American, and White). Mean verbal, nonverbal, and composite IQ scores as measured by the Kaufman Brief Intelligence Test-2 (KBIT-2; Kaufman \& Kaufman, 2004) were $79.46(\mathrm{SD}=14.78$; range $=40-108), 81.73(\mathrm{SD}=$ $14.90 ;$ range $=40-115)$, and $77.92(\mathrm{SD}=14.88 ;$ range $=40-113)$, respectively. A parent of 112 of 115 children completed the Anxiety Disorders Interview Schedule, Parent Version (ADIS-P; Silverman \& Albano, 1996). Based on this interview, 85 children (75.9\%) met DSM-IV criteria for at least one anxiety disorder, and 27 children (24.1\%) did not meet criteria for any DSM-IV anxiety disorder. All of the children who were diagnosed with at least one anxiety disorder met diagnostic criteria for specific phobia. In addition, 4 children (3.6\%) also were diagnosed with generalized anxiety disorder; 1 child (0.9\%) also met diagnostic criteria for separation anxiety disorder; 1 child $(0.9 \%)$ also met diagnostic criteria for social phobia; and 1 child $(0.9 \%)$ also met diagnostic criteria for separation anxiety disorder and social phobia. 


\section{Measures}

Four of the parent-report measures included in the ongoing investigation of development in WS were used in the current study. All measures were completed and scored according to the test authors' standardized procedures.

Independent Variables. Negative Reactivity. Children's Behavior Questionnaire - Long form (CBQ; Rothbart et al., 2001). The CBQ is a parent-report measure of child temperament developed for use with TD children between 3 and 7 years of age; it is often used through age 10 years with children who have developmental disabilities (e.g., KleinTasman \& Mervis, 2003; Leyfer et al., 2012). The long form of the CBQ includes 327 items and 23 scales. Possible responses to the items range from "very untrue" (a score of 1) to "very true" (a score of 7). This measure contains three broad dimensions of temperament: negative affectivity, effortful control, and extraversion/surgency. The CBQ has adequate psychometric properties including stability estimates (ranging from .48 to .79 ) and internal consistency coefficients (ranging from .64 - .92). The scales that comprise the negative affectivity factor include a total of 62 items, with internal consistency ranging from $.67-.80$. The validity of the negative affectivity factor has been demonstrated through confirmatory factor analysis both in the United States and cross-culturally (Ahadi, Rothbart, \& Ye, 1993; Rothbart et al., 2001). The mean of the mean scores for the scales included on the negative affectivity factor (discomfort, sadness, fear, anger/frustration, soothability) was used in the current study to measure negative reactivity. Lower scores indicate less negative reactivity

Sensory Modulation Difficulties. Short Sensory Profile (SSP; McIntosh et al., 1999). The SSP is a caregiver-report rating scale used to measure sensory modulation, 
developed for use with children between the ages of $3-10$ years. The SSP includes 38 items and 7 subscales (tactile sensitivity, movement sensitivity, visual/auditory sensitivity, taste/smell sensitivity, auditory filtering, low energy/weak, and underresponsive/seeks sensation) and yields a total sensory modulation score. Possible responses to the items range from "always" (a score of 1) to "never" (a score of 5). The measure has acceptable psychometric properties, including internal consistency scores ranging from $.82-.96$. The total sensory modulation score is the sum of the scores for all 38 items and has a reliability estimate of .96 , with intercorrelation scores between the total and section scores ranging from $.48-.80$. Higher scores indicate better functioning. The total sensory modulation score was used in the current study to measure sensory modulation difficulties. Scores of 142 - 154 are in the test authors' "probable difference" range, and scores of 141 or below are in the "definite difference" range.

Self-Regulation Problems. Behavior Rating Inventory of Executive Functioning (BRIEF; Gioia et al., 2000). The BRIEF is an 86-item questionnaire for parents of $6-18$ year-olds regarding executive functioning behaviors at home and at school. Possible responses to the items range from "never" (a score of 1) to "often" (a score of 3). The BRIEF includes 8 scales and yields two summary indices and an overall composite, each reported as a $\mathrm{T}$ score $($ mean $=50, \mathrm{SD}=10$; lower scores indicate better functioning). The Behavioral Regulation Index includes 28 items and measures the ability to shift cognitive set and to use inhibitory control to monitor both emotions and behavior. The Behavioral Regulation Index has adequate psychometric properties, including test-retest reliability (.92) and internal consistency (ranging from .94 - .96) and has been shown to correlate with measures of hyperactivity and impulsivity. The Behavioral Regulation Index T- 
score was used in the current study to represent self-regulation abilities. T-scores of 65 or above are considered to be in the "abnormally elevated" range by the test authors.

Dependent Variable. Anxiety Symptoms. Child Behavior Checklist 6-18 (CBCL; Achenbach \& Rescorla, 2001). The CBCL 6 - 18 is a 113-item caregiver-report rating scale used to assess a variety of childhood behaviors. Possible responses to the items are "not true (as far as you know)" (a score of 0), "somewhat or sometimes true" (a score of 1), and "very true or often true" (a score of 2). The DSM-IV Anxiety Problems subscale includes six items that have been selected by experts to represent commonly experienced symptoms of anxiety disorders. The items are as follows: 1 . Clings to adults or too dependent; 2. Fears certain animals, situations, or places, other than school; 3. Fears going to school; 4. Nervous, highstrung, or tense; 5. Too fearful or anxious; 6. Worries. This scale has adequate test-retest reliability (.80), internal consistency (.72), and cross-informant agreement (.66) and has been shown to be associated with having an anxiety disorder diagnosis $(\mathrm{kappa}=.34)$. The DSM-IV Anxiety Problems subscale Tscore $($ mean $=50, \mathrm{SD}=10$; lower scores indicate less anxiety) was used to measure anxiety symptoms in this study. T-scores of $65-69$ are considered to be in the "borderline clinical" range by the test authors, and T-scores of 70 or above are considered to be in the "clinical" range.

\section{Results}

\section{Descriptive Statistics}

Prior to conducting analyses, the distributions of the variables (negative reactivity, self-regulation problems, sensory modulation difficulties, and anxiety symptoms) were examined visually by plotting histogram scores along the normal curve. In addition, 
measures of skewness and kurtosis were referenced to further examine variable normality. All distributions appeared to be normally distributed and did not violate assumptions for further statistical analyses. Descriptive statistics are included in Table 2.

Table 2

Descriptive Statistics for Negative Reactivity, Sensory Modulation Difficulties, SelfRegulation Problems, and Anxiety Symptoms

\begin{tabular}{lccc}
\hline \multicolumn{1}{c}{ Variable } & Mean & Standard Deviation & Range \\
\hline Negative Reactivity & 4.16 & 0.58 & $2.53-5.58$ \\
$\begin{array}{l}\text { Sensory Modulation } \\
\text { Difficulties }\end{array}$ & 131.91 & 19.52 & $93-178$ \\
Self-regulation Problems & 63.16 & 10.32 & $39-85$ \\
& 60.41 & 8.11 & $50-77$ \\
\hline
\end{tabular}

Thirteen $(11.3 \%)$ of the children earned scores within the normal range on the SSP, $26(22.6 \%)$ scored in the probable difference range, and $76(66.1 \%)$ scored in the definite difference range. On the BRIEF Behavioral Regulation Index, 63 (54.8\%) of the children received T-scores within the normal range and $52(45.2 \%)$ earned $\mathrm{T}$-scores within the abnormally elevated range. On the CBCL DSM-IV Anxiety Problems Scale, $71(61.7 \%)$ of the children had T-scores within the normal range, $23(20 \%)$ had T-scores within the borderline clinical range, and $21(18.3 \%)$ had T-scores within the clinical range. 
Bivariate correlations were conducted to examine the potential relation between CA and negative reactivity, sensory modulation difficulties, self-regulation problems, and anxiety symptoms (see Table 3). All correlations with CA were non-significant. In addition, bivariate correlations were conducted to examine the potential relation between intellectual ability (KBIT-2 composite IQ score) and negative reactivity, sensory modulation difficulties, self-regulation problems, and anxiety symptoms (see Table 3). All correlations were nonsignificant with the exception of sensory modulation difficulties $(r=.29, p=.002)$, indicating that less difficulty with sensory modulation is associated with higher intellectual ability. For these correlational analyses, alpha was set at .006 $(.05 / 8)$ to take into account the multiple analyses conducted.

Table 3

Pearson Correlations Between Chronological Age, IQ, Negative Reactivity, Sensory Modulation Difficulties, Self-regulation Problems, and Anxiety Symptoms

\begin{tabular}{|c|c|c|c|c|c|c|}
\hline & $\begin{array}{c}\text { Chronological } \\
\text { Age }\end{array}$ & IQ & $\begin{array}{l}\text { Negative } \\
\text { Reactivity }\end{array}$ & $\begin{array}{c}\text { Sensory } \\
\text { Modulation } \\
\text { Difficulties }\end{array}$ & $\begin{array}{c}\text { Self- } \\
\text { regulation } \\
\text { Problems } \\
\end{array}$ & $\begin{array}{c}\text { Anxiety } \\
\text { Symptoms }\end{array}$ \\
\hline $\begin{array}{l}\text { Chronological } \\
\text { Age }\end{array}$ & -- & -.19 & .09 & -.04 & .04 & .17 \\
\hline IQ & -- & -- & .12 & $.29 *$ & -.13 & -.07 \\
\hline $\begin{array}{l}\text { Negative } \\
\text { Reactivity }\end{array}$ & -- & -- & -- & $-.44 * *$ & $.57 * *$ & $.48 * *$ \\
\hline $\begin{array}{l}\text { Sensory } \\
\text { Modulation } \\
\text { Difficulties }\end{array}$ & -- & -- & -- & -- & $-.56 * *$ & $-.53 * *$ \\
\hline $\begin{array}{l}\text { Self- } \\
\text { regulation } \\
\text { Problems }\end{array}$ & -- & -- & -- & -- & -- & $.47 * *$ \\
\hline
\end{tabular}

$* p<.005$ (2-tailed)

$* * p<.001$ (2-tailed) 


\section{Hypothesis 1: The shared variance among negative reactivity, sensory modulation}

difficulties, and self-regulation problems in children with Williams syndrome is adequately represented by a single underlying 'behavioral phenotype' factor. An exploratory factor analysis (EFA) was conducted to test the first hypothesis of a shared underlying 'behavioral phenotype' factor in children with WS. EFA is a multivariate technique based on the general linear model. It examines the pattern of correlations between observed variables and attempts to create parsimony through identifying underlying latent factors that may explain shared variance found in the data (Field, 2005). Bivariate correlations between the variables of negative reactivity, sensory modulation difficulties, and self-regulation are shown in Table 3. Alpha was set at .008 $(.05 / 6)$ to take into account the multiple analyses conducted. All correlations were significant at $p<.001$.

EFA Sample Adequacy. Common suggestions for minimum sample size in EFA vary from 5-20 participants per variable (Costello \& Osborne, 2005; Field, 2005; Kass \& Tinsley, 1979); the current sample size of 115 participants exceeded these minimum recommendations. Adequacy of sample size was examined using the Kaiser-Mayer-Olkin measure of sampling adequacy (KMO) and Bartlett's test of sphericity. KMO is a statistic that yields a proportion of squared correlation to squared partial correlation between variables, and Bartlett's test of sphericity compares the correlation matrix for the observed data to an identity matrix. KMO values $>.5$ are generally considered acceptable (Kaiser, 1974). Results from both tests supported sample adequacy: KMO = .679 ; Bartlett's test of sphericity: $X^{2}(3)=89.36, p<.001$. 
Factor Extraction. Given the significant covariance found between the variables (negative reactivity, sensory modulation difficulties, and self-regulation problems), data normality, and desire to generalize results from the current sample, EFA with Maximum Likelihood extraction method was chosen for further analyses (Costello \& Osborne, 2005). As high levels of collinearity are often found in data from individuals with WS (Crawford, John, Woodruff-Borden, \& Mervis, 2008), it was assumed that if more than one latent factor emerged from the data they would be correlated, making Principal Component Analysis less appropriate. Indicators for the 'behavioral phenotype' factor included the CBQ negative affectivity factor score, SSP total sensory modulation score, and the BRIEF Behavior Regulation Index T score.

An examination of Eigenvalues, the scree-plot, and a parallel analysis were used to determine the number of meaningful factors to retain from the EFA. A parallel analysis compares the observed Eigenvalues to those for a randomly generated dataset to determine if the obtained factor structure is a significantly better fit for the observed data. The factor score coefficient values for each individual included in the sample were calculated using the regression method. The regression method was chosen because it is a refined method that maximizes validity with both orthogonal and oblique rotations, particularly for a one-factor solution (DiStefano, Zhu, \& Mindrila, 2009). An examination of the scree-plot showed a clear drop from one to two factors, with minimal change between two and three factors. Eigenvalues were as follows: One-factor $=2.047$; Two-factor $=0.558$; Three-factor $=0.394$. The total variance explained by a one-factor solution, after sums of squared loading extraction, was $53.37 \%$. Results from a parallel 
analysis using 200 generated datasets at the $95^{\text {th }}$ percentile provided additional support for a one-factor solution (see Table 4).

Table 4

Parallel Analysis Results

\begin{tabular}{lccc}
\hline & $\begin{array}{c}\text { Raw data } \\
\text { Eigenvalue }\end{array}$ & Mean & Percentile \\
\hline One-factor & 1.43 & .17 & .29 \\
Two-factor & -.10 & .00 & .08 \\
Three-factor & -.20 & -.12 & -.05 \\
\hline
\end{tabular}

Factor loadings, following Maximum Likelihood extraction, were as follows: negative reactivity $=.673$, sensory modulation difficulties $=-.657$, self-regulation problems $=.847$. The obtained communalities after extraction (using Maximum Likelihood: negative reactivity $=.453$; sensory modulation difficulties $=.432$; selfregulation problems $=.717$ ) were acceptable, providing further support for sample size adequacy (Costello \& Osborne, 2005). Taken together, the results support the hypothesis of a one-factor latent 'behavioral phenotype' factor extracted from the shared variance of negative reactivity, sensory modulation difficulties, and self-regulation problems. 
Hypothesis 2: The shared variance found in the 'behavioral phenotype' factor has a significant relation with anxiety symptoms in children with Williams syndrome, yielding a medium to large effect size.

To test the second hypothesis of a significant relation between the 'behavioral phenotype' factor and anxiety symptoms in children with WS, factor score coefficient values were entered into a regression model as a predictor, with the CBCL DSM-IV Anxiety Problems subscale T-score serving as the dependent variable. The model provided a significant fit to the data, $(F(1,113)=53.81, p<.001)$, yielding a large effect size $(r=0.57)$ and explaining $32.3 \%$ of the variance in anxiety symptoms. These results support the hypothesis that scores on the 'behavioral phenotype' factor share a significant association with anxiety symptoms in children with Williams syndrome aged $6-10$ years. 


\section{CHAPTER III \\ GENERAL DISCUSSION}

The purpose of this dissertation was to explore the relations of negative reactivity, problems with self-regulation, and sensory modulation difficulties to the increased prevalence of anxiety symptoms in children with WS. Study hypotheses were: (1) The shared variance between negative reactivity, self-regulation problems, and sensory modulation difficulties will be adequately represented by a single underlying 'behavioral phenotype' factor. (2) This factor will share a significant relation with anxiety symptoms in children with WS. The discussion is organized into four sections. The results are first discussed within the framework of the two hypotheses in sections one and two, followed by the implications of these findings for future research and anxiety treatment in children with WS in sections three and four.

\section{Williams Syndrome 'Behavioral Phenotype' Factor}

The first hypothesis, that an underlying latent 'behavioral phenotype' factor would be uncovered from the shared variance between measures of negative reactivity, self-regulation problems, and sensory modulation difficulties, was supported. Significant bivariate correlations were found between each pair of variables with medium to large effect sizes, suggesting that these features demonstrate considerable overlapping variance. A one-factor latent model was uncovered using exploratory factor analysis, with each feature providing a significant factor loading to the 'behavioral phenotype' 
factor. These findings are consistent with what has been found in the literature: the behavioral features of negative reactivity (e.g., Davies et al., 1998), poor self-regulation (e.g., Woodruff-Borden et al., 2010), and sensory modulation difficulties (e.g., John \& Mervis, 2010) are associated with the WS phenotype. While these aspects of the WS behavioral phenotype have been documented in the literature, previous studies have not statistically examined the overlap of these three features as an underlying phenotype factor. This is the first study to examine the latent structure of a unifying behavioral phenotype factor found in the observed covariance of negative reactivity, self-regulation problems, and sensory modulation difficulties.

Further support for the existence of a behavioral phenotype factor that includes features of reactivity, regulation, and sensory activation is provided from neurobiological findings of individuals with WS. Meyer-Lindenberg et al. (2005) found that individuals with WS demonstrated excessive neural reactivity in the amygdala in response to nonsocial stimuli, with functional deactivation of the OFC. Biologically, negative reactivity has been associated with the neuroanatomical substrates of the amygdala and self-regulation has been associated with the OFC (Whittle et al., 2006), with both substrates receiving projections from sensory cortices. These neuronal patterns of excessive reactivity with decreased activation of regulatory regions, in combination with the current finding of an underlying behavioral phenotype factor between measures of reactivity and regulation, suggest that negative reactivity, self-regulation problems, and sensory modulation difficulties are biologically influenced by the WS genotype. 


\section{Association Between Williams Syndrome 'Behavioral Phenotype' Factor and}

\section{Anxiety Symptoms}

The second hypothesis, that the 'behavioral phenotype' factor shares a significant relation with anxiety symptoms in children with WS, was also supported. Specifically, the variance found in the 'behavioral phenotype' factor scores significantly predicted anxiety symptoms using a regression model, yielding a large effect size. These results are consistent with prior findings of associations between negative reactivity (Leyfer et al., 2012), self-regulation problems (Leyfer et al. 2012; Woodruff-Borden et al., 2010), and sensory modulation difficulties (John \& Mervis, 2010) with anxiety in children with WS. This is the first study to examine the association of the shared behavioral phenotype features of negative reactivity, self-regulation problems, sensory modulation difficulties, with anxiety symptoms in children with WS.

The findings of this study are also consistent with associations found between negative reactivity, self-regulation problems, and sensory modulation difficulties in both the TD and autism literatures. In particular, research findings point toward the interplay of high levels of negative reactivity and low levels of self-regulation as risk factors for experiencing childhood anxiety symptoms (Anthony et al., 2002; Eisenberg et al., 2001;

Lonigan et al., 2004; Meesters et al., 2007). A specific emphasis on the regulatory role of attentional control in association with anxiety has been underscored in the TD literature (Muris et al., 2004; Verstraeten et al., 2010). Further, sensory sensitivity has been associated with anxiety symptoms in both TD children (Ben-Sasson et al., 2009; Goldsmith et al., 2006; Reynolds \& Lane, 2009) and children with autism spectrum disorder (Ben-Sasson et al., 2008; Pfeiffer et al., 2005; Tsuji et al., 2009) and has been 
shown to precede increases in anxiety levels in a longitudinal study of young children with autism spectrum disorder (Green et al., 2012).

From a neurobiological perspective, sensory over-responsivity is associated with central nervous system arousal through sensory cortex projections to the amygdala and OFC (Iversen, Kupfermann, \& Kandel, 2000; Lane, 2002). In this view, incoming sensory information can create amygdala reactivity resulting in hypervigilance functions such as autonomic arousal and scanning the environment for threat/automatic narrowing of attention, as well as activate $\mathrm{OFC}$ regulatory functions such as behavioral/emotional inhibition and attentional control (Kringelbach \& Rolls, 2004; Milad \& Rauch, 2007; Zald, 2003). Milad and Rauch (2007) have hypothesized that heightened amygdala reactivity in combination with OFC regulatory dysfunction may increase the risk of experiencing anxiety disorders. Further, emerging evidence suggests that the association between hypervigilant attentional narrowing on threatening information and anxiety symptoms in children is modulated through self-regulatory aspects of attentional control (Susa, Pitica, Benga, \& Miclea, 2012). Therefore, the observed pattern of amygdala hyperactivation with dysregulated OFC connectivity found in individuals with WS (Meyer-Lindenberg et al., 2005) may increase the likelihood of experiencing hypervigilance, fear, and chronic anxiety in the absence of true threat, with a decreased ability to modulate these experiences. The results of this study provide further evidence for this view through the observed association of the behavioral phenotype features of sensory modulation difficulties, increased negative reactivity, and poor self-regulation abilities with anxiety symptoms in children with WS. 
In summary, the findings of the current study confirmed both hypotheses: (1) The results of an exploratory factor analysis indicated that the shared variance between measures of negative reactivity, self-regulation problems, and sensory modulation difficulties was adequately represented statistically through a single underlying 'behavioral phenotype' latent factor. (2) The results of a regression analysis indicated that the 'behavioral phenotype' factor scores shared a significant association with anxiety symptoms in children with WS, yielding a large effect size. These findings demonstrate the overall contribution of three behavioral phenotype features associated with the WS 7q11.23 genotype to the concurrent variance in anxiety symptoms for children with WS aged $6-10$ years.

\section{Implications for Future Research}

The current study investigated associations with anxiety in children with WS using salient aspects of the behavioral phenotype. While the findings suggest the possibility of an important role of the behavioral phenotype features of negative reactivity, self-regulation problems, and sensory modulation difficulties in anxiety symptoms, causation cannot be established. Further, additional environmental influences that are not directly related to the behavioral phenotype, such as stressful life events or parenting practices, were not considered in this study and may also share an important association with anxiety symptoms helping to further explain variance not accounted for in the current model. Nevertheless, these findings underscore the importance of examining the role these behavioral phenotype features share in the emergence and maintenance of anxiety in children with WS. Three questions provide a good starting point for future research. (1) Do certain aspects of the behavioral phenotype precede the 
emergence of anxiety symptoms in children with WS? For example, are difficulties modulating sensory over-reactivity present prior to anxiety symptoms? (2) Do certain aspects of each of the three behavioral phenotype features share a stronger relation to anxiety symptoms than other aspects for children with WS? For instance are all components of negative reactivity (discomfort, sadness, fear, anger/frustration, difficulty with soothability) equally related to increased anxiety for children with WS, or are some of these components, such as fearful reactivity, more closely related than others? (3) How do aspects of the three behavioral phenotype features differentially influence the probability of children with WS being diagnosed with an anxiety disorder? For example, do children with WS who have an anxiety disorder demonstrate different patterns of hypervigilant reactivity and regulatory responses, such as heightened attentional narrowing and avoidance of feared stimuli, than do those who do not have an anxiety disorder?

Emerging evidence from the autism literature suggests that sensory difficulties emerge prior to anxiety symptoms and predict changes in anxiety level across time (Green \& Ben-Sasson, 2012). Green and Ben-Sasson (2010) proposed an explanatory model of anxiety disorders for children with autism spectrum disorders with an emphasis on the role of sensory over-responsivity as a primary risk factor. In this model, an anxiety disorder may be influenced by the classical conditioning of fear in response to aversive sensory reactions to specific stimuli and/or the generalization of this conditioning to broader contexts, leading to anxiety. Adapting this model to the current understanding of anxiety in children with WS can help inform further exploration of the previously mentioned research questions (see Figure 3). As previously discussed, the 
sensory modulation difficulties individuals with WS experience may cause significant reactivity in the amygdala, resulting in a hypervigilant "fight or flight" response. Aspects of hypervigilance, such as environmental scanning and attentional narrowing toward threatening stimuli, may increase the likelihood of individuals with WS pairing an unconditioned stimulus (e.g., loud noise) with a conditioned stimulus (e.g., vacuum) or context (e.g., gymnasium). This hypervigilance then increases level of negative reactivity stress response which is poorly regulated leading to maladaptive coping mechanisms such as avoidance and feelings of unpredictability/uncontrollability in regard to experiencing specific situations in the future (e.g., being in a gymnasium) or broadly generalized to future events. Individuals with WS often experience chronic and intense preoccupations with future-oriented events, particularly situations or contexts that are associated with reported sensory sensitivity and/or feelings of anticipation. These selfregulation problems, maladaptive coping mechanisms, and feelings of unpredictability/uncontrollability may further exacerbate nervous system hypervigilance, setting the stage for chronic anxiety. 


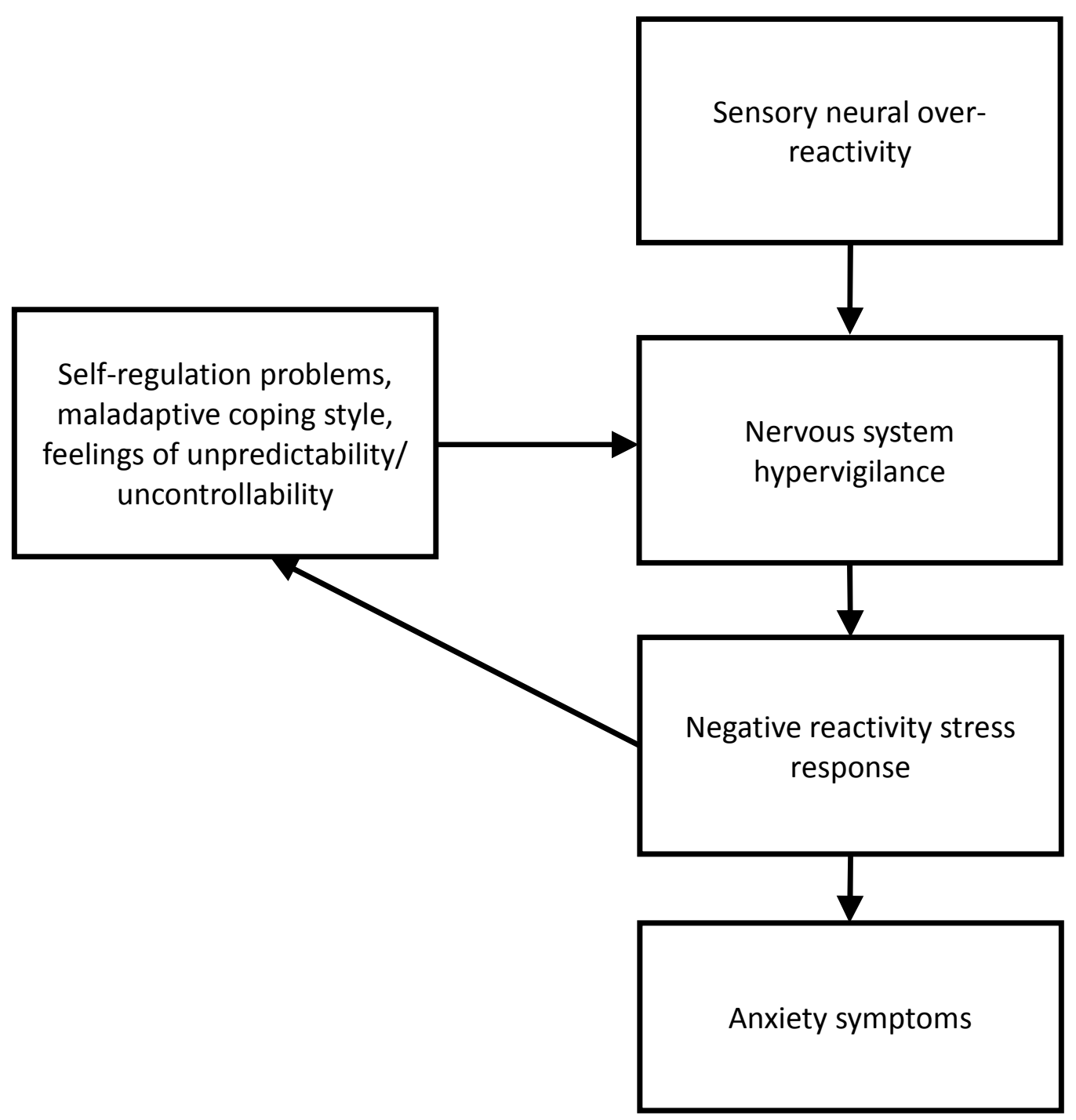

Figure 3. Schematic depiction of theoretical pathway for anxiety in WS.

Future research should test the relative contribution of each pathway to future symptoms of anxiety in children with WS. For example, one could examine the statistical model fit of the association between sensory neural over-reactivity, nervous system hypervigilance, heightened levels of negative reactivity, and self-regulation problems with anxiety symptoms at Time 1, and with anxiety symptoms 5 years later (Time 2), with a focus on the significance and strength of each pathway. This would help answer the research question of whether certain features of the WS behavioral phenotype 
precede the emergence of anxiety symptoms or are primarily related to concurrent symptoms.

Further, specific aspects of each behavioral phenotype feature included in this model should be examined in children with WS. For instance, separate indicators for components of sensory neural over-reactivity, nervous system hypervigilance, negative reactivity stress responses, and self-regulation problems as latent variables could be included. This may help address the question of whether certain aspects of each behavioral phenotype feature (negative reactivity, self-regulation problems, and sensory modulation difficulties) share a stronger relation to anxiety symptoms than others for children with WS.

In addition, this model should be compared between individuals with WS who have anxiety disorders and those who do not. Specifically, the equivalencies of levels of specific aspects of sensory neural over-reactivity (e.g., tactile sensitivity, movement sensitivity, visual/auditory sensitivity, taste/smell sensitivity, auditory filtering), nervous system hypervigilance (e.g., attentional narrowing and electrodermal activity to environmental stimuli) negative reactivity (e.g., fearful reactivity and anger/frustration), and self-regulation problems (e.g., attentional shifting, avoidance of stimuli) as latent factors predicting anxiety symptoms can be compared across individuals with WS who do and do not have an anxiety disorder, through invariance testing. Children with anxiety disorders have been shown to demonstrate increased difficulties in many of these areas suggesting that aspects of the behavioral features may be statistically different for children with WS who have an anxiety disorder compared to those who do not. Elucidating the influence and interaction of aspects of these behavioral phenotype 
features on the emergence and/or maintenance of anxiety symptoms will heighten the current understanding of anxiety in children with WS as well as inform future treatment studies.

\section{Implications for Treatment of Anxiety in Williams Syndrome}

The findings from the current study suggest that aspects of the WS behavioral phenotype share a significant association with anxiety symptoms in children. These findings suggest that both heightened reactivity and poor regulatory abilities may influence the nature and course of anxiety for individuals with WS and can help inform intervention approaches to alleviate and prevent these problems. Specifically, treatment addressing sensory modulation difficulties and/or poor self-regulation of negative reactivity provides good points for intervention. As discussed in the previous section, sensory over-reactivity may share an important association with anxiety in children with WS through hypervigilant activation of the nervous system. In this view, improving the modulation of sensory over-reactivity may help decrease fear conditioning and generalized feelings of uncontrollability associated with anxiety.

Evidence for the reduction of anxiety symptoms through sensory-based interventions has been demonstrated for both individuals with autism and TD individuals. Edelson, Edelson, Kerr, and Grandin (1998) conducted a treatment study investigating the effect of deep pressure treatment on anxiety in children with autism. The results showed that compared to a placebo control group of children with autism, children who received 12 sessions of deep pressure treatment over 6 weeks demonstrated significantly lower levels of tension after the $12^{\text {th }}$ session. Further, in a treatment study of anxiety in TD adults, a significant reduction in anxiety level was demonstrated following 4 weeks of 
daily exposure to personalized aversive sensory stimuli ("sensory diet") in the home setting (Pfeiffer \& Kinnealey, 2003). The results of these treatment studies provide evidence for the potential of decreasing anxiety through sensory-modulation interventions in individuals with increased risk for sensory difficulties. Tailoring treatment programs to address the specific sensory difficulties that many individuals with WS experience may prove promising for the reduction of anxiety symptoms. For example, helping individuals with WS to modulate symptoms of sensory over-reactivity may decrease nervous system hypervigilance, decreasing the probability of experiencing fear conditioning and the generalization of uncontrollability feelings to multiple contexts. In addition, a reduction of the hypervigilance aspects of environmental scanning and attentional narrowing (henceforth, "attentional bias") toward threatening stimuli may help to decrease negative reactivity stress responses in children with WS. TD children who completed a computerized training program designed to induce an attentional bias toward threatening stimuli demonstrated increased levels of anxiety following a stressinduction task compared to children who completed training for attentional bias toward neutral stimuli (Eldar, Ricon, \& Bar-Haim, 2008). Further, Rozenman, Weersing, and Amir (2011) found that children with anxiety disorders who completed 12 sessions of attentional bias training designed to direct automatic attention away from threat demonstrated a significant decrease in anxiety level, with $75 \%$ of treated children no longer meeting criteria for an anxiety disorder at post-treatment assessment. The results of these treatment studies provide evidence for the potential of decreasing anxiety through attention bias training in TD children. Individuals with WS diagnosed with anxiety disorders have been shown to demonstrate a significantly larger attentional bias 
to threatening stimuli than do individuals with WS without an anxiety disorder (Dodd \& Porter, 2011b). The results of this study suggest that the attentional bias aspect of nervous system hypervigilance may be heightened for individuals with WS who experience chronic and clinical levels of anxiety, although caution should be made interpreting the results of this study given the small number of individuals with an anxiety disorder included in the analyses $(\mathrm{N}=7)$. Attention bias training may help to reduce nervous system hypervigilance for individuals with WS, decreasing the overall level of negative reactivity stress responses and making self-regulation of these responses more manageable.

Finally, modified cognitive-behavioral therapy (CBT) approaches have been shown to effectively reduce anxiety in children with autism spectrum disorder. Specifically, self-regulation intervention strategies such as coping self-talk, relaxation techniques, and modeling/role-playing effective coping strategies have been employed. Chalfant, Rapee, and Carroll (2007) found that children with autism and an anxiety disorder demonstrated significantly decreased levels of anxiety compared to wait-listed children following a group CBT intervention program, with a $71.4 \%$ reduction in anxiety diagnosis post-treatment. Similarly, children with Asperger syndrome were found to demonstrate a significant decrease in anxiety level following 6 sessions of CBT (Sofronoff, Attwood, \& Hinton, 2005). The results of these treatment studies provide evidence for decreasing anxiety through CBT intervention techniques in children with autism spectrum disorders.

CBT also may prove effective in reducing anxiety for children with WS, particularly through in-vivo exposure to stimuli associated with conditioned fear, with a 
focus on increasing self-regulatory coping skills. Several case studies involving adapted CBT interventions have been reported for individuals with WS. For example, KleinTasman and Albano (2007) found that role-playing coping skills during an exposure for obsessive sexual thoughts decreased socially inappropriate behaviors for a college-aged individual with WS. In addition, behaviorally-focused interventions with parent training have been shown to successfully decrease self-injurious behaviors in a 7-year-old child with WS (Conelea \& Klein-Tasman, 2013), food refusal in a 4-year-old child with WS (O'Reilly \& Lancioni, 2001), as well as emotional outbursts and repetitive question asking in two adolescents with WS (Phillips \& Klein-Tasman, 2009), underscoring the importance of parental involvement in treatment. Preliminary evidence from these case studies suggests that behaviorally-focused aspects of CBT with parental involvement helps reduce problem behaviors in individuals with WS. Applying CBT intervention techniques with an emphasis on increasing self-regulation and effective coping of negative reactivity stress responses, as well as managing feelings of uncontrollability/unpredictability about the future, may prove promising for reducing anxiety in children with WS.

\section{Conclusion}

This is the first study to examine the combined association of the WS behavioral phenotype features of negative reactivity, self-regulation problems, and sensory modulation difficulties with anxiety symptoms in children with WS. The results demonstrated a significant association between the shared variance of these features and anxiety in children with WS aged $6-10$ years. These findings help to clarify the current 
understanding of anxiety symptoms in children with WS by highlighting the relation with features associated with the biological phenotype.

The current literature on anxiety in individuals with WS has demonstrated increased prevalence for both anxiety symptoms and disorders. However, the nature and course of these problems are not well understood. Using the phenotype features to better understand factors associated with anxiety symptoms may prove promising for furthering the understanding of why individuals with WS are at such an increased risk for anxiety problems and may help to inform prevention and intervention efforts.

Future research studies should examine the relative contribution of each behavioral phenotype feature to future symptoms of anxiety in children with WS. In addition, levels of specific aspects of each behavioral phenotype feature should be examined separately in children with WS who meet diagnostic criteria for at least one anxiety disorder and children with WS who do not meet diagnostic criteria for any anxiety disorder. Longitudinal studies will help to uncover potential causal pathways between phenotype factors and anxiety in children with WS. Using these findings to tailor interventions for anxiety in children with WS with a specific focus on increasing self-regulation and decreasing sensory modulation difficulties may help alleviate impairment and increase psychosocial functioning for these individuals. 


\section{REFERENCES:}

Achenbach, T. M. (1991). Manual for the Child Behavior Checklist/4-18. Burlington, VT: University of Vermont.

Achenbach, T. M., \& Edelbrock, C. (1983). The Child Behavior Checklist for ages 4 16. Burlington, VT: University of Vermont.

Achenbach, T. M., \& Rescorla, L. A. (2000). Manual for the ASEBA preschool forms \& profiles. Burlington, VT: University of Vermont.

Achenbach, T. M., \& Rescorla, L. A. (2001). Manual for the ASEBA school-age forms \& profiles. Burlington, VT: University of Vermont.

Ahadi, S. A., Rothbart, M. K., \& Ye, R. M. (1993). Children's temperament in the U.S. and China: Similarities and differences. European Journal of Personality, 7, 359-377.

American Psychiatric Association. (2000). Diagnostic and statistical manual of mental disorders ( $4^{\text {th }}$ ed., text revision). Washington, D.C.: American Psychiatric Association.

Anderson, J. C., Williams, S. M., McGee, R., \& Silva, P. A. (1987). DSM-III disorders in preadolescent children: Prevalence in a large sample from the general population. Archives of General Psychiatry, 44, 69-76.

Anthony, J. L., Lonigan, C. J., Hooe, E. S., \& Phillips, B. M. (2002). An affect-based, hierarchical model of temperament and its relations with internalizing 
symptomology. Journal of Clinical Child and Adolescent Psychology, 31, 480-490

Attias, J., Raveh, E., Ben-Naftali, N. F., Zarchi, O., \& Gothelf, D. (2008). Hyperactive auditory efferent system and lack of acoustic reflexes in Williams syndrome. Journal of Basic and Clinical Physiology and Pharmacology, 19, 193-207.

Arnold, R., Yule, W., \& Martin, N. (1985). The psychological characteristics of infantile hypercalcemia: A preliminary investigation. Developmental Medicine \& Child Neurology, 27, 49-59.

Barlow, D. (2002). The nature of anxious apprehension. In D. H. Barlow, Anxiety and its disorders: The nature and treatment of anxiety and panic, ( $2^{\text {nd }}$ ed., pp. 64-104). New York, NY: Guilford Press.

Barrett, P. M., Rapee, R. M., Dadds, M. M., \& Ryan, S. M. (1996). Family enhancement of cognitive style in anxious and aggressive children. Journal of Abnormal Child Psychology, 24, 187-203.

Ben-Sasson, A., Carter, A. S., \& Briggs-Gowan, M. J. (2009). Sensory over-responsivity in elementary school: Prevalence and social-emotional correlates. Journal of Abnormal Child Psychology, 37, 705-716.

Ben-Sasson, A., Cermak, S., Orsmond, G., Tager-Flusberg, H., Kadlec, M., \& Carter, A. (2008). Sensory clusters of toddlers with autism spectrum disorders: differences in affective symptoms. Journal of Child Psychology and Psychiatry, 49, 817-825.

Block, J., \& Block, J. (1980). The role of ego-control and ego-resiliency in the organization of behavior. In W.A. Collins (Ed.) Development of cognition, affect, and social relations: The Minnesota symposia on child psychology (Vol. 13). Hillsdale, NJ: Erlbaum. 
Burke, K., Burke Jr, J., Regier, D., \& Rae, D. (1990). Age at onset of selected mental disorders in five community populations. Archives of General Psychiatry, 47, 511-518.

Chalfant, A. M., Rapee, R., \& Carroll, L. (2007). Treating anxiety disorders in children with high functioning autism spectrum disorders: A controlled trial. Journal of Autism and Developmental Disorders, 37, 1842-1857.

Cherniske, E. M., Carpenter, T. O., Klaiman, C., Young, E., Bregman, J., Insogna, K.,...Pober, B. R. (2004). Multisystem study of 20 older adults with Williams syndrome. American Journal of Medical Genetics, 131A, 255-264.

Cohen, J. (1992). A power primer. Psychological Bulletin, 112, 155-159.

Conelea, C. A., \& Klein-Tasman, B. P. (2013). Habit reversal therapy for body-focused repetitive behaviors in Williams syndrome: A case study. Journal of Developmental and Physical Disabilities, 25, 597-611.

Costello, A. B., \& Osborne, J. W. (2005). Best Practices in exploratory factor analysis: Four recommendations for getting the most from your analysis. Practical Assessment, Research \& Evaluation, 10, 1-9.

Crawford, N., John, A., Woodruff-Borden, J., \& Mervis, C. B. (July, 2008). Sensory processing difficulties predict internalizing symptoms, ADHD symptoms, and repetitive behaviors in 4-10-year-old children with Williams syndrome. Poster presented at the $12^{\text {th }}$ International Professional Conference on Williams syndrome, Garden Grove, CA.

Craske, M., Poulton, R., Tsao, J., \& Plotkin, D. (2001). Paths to panic disorder/agoraphobia: an exploratory analysis from age 3 to 21 in an unselected 
birth cohort. Journal of the American Academy of Child \& Adolescent Psychiatry, $40,556-563$.

Creswell, C., Schniering, C. A., \& Rapee, R. M. (2005). Threat interpretation in anxious children and their mothers: Comparison with nonclinical children and the effects of treatment. Behaviour Research and Therapy, 43, 1375-1381.

Crnic, K., Hoffman, C., Gaze, C., \& Edelbrock, C. (2004). Understanding the emergence of behavior problems in young children with developmental delays. Infants \& Young Children, 17, 223-235.

Davies, M., Udwin, O., \& Howlin, P. (1998). Adults with Williams syndrome. Preliminary study of social, emotional and behavioural difficulties. The British Journal of Psychiatry, 172, 273-276.

Dekker, M. C., \& Koot, H. M. (2003). DSM-IV disorders in children with borderline to moderate intellectual disability. I: Prevalence and impact. Journal of the American Academy of Child and Adolescent Psychiatry, 42, 915-922.

Derryberry, D., \& Reed, M. A. (1996). Regulatory processes and the development of cognitive representations. Developmental Psychopathology, 8, 215-234.

Dilts, C., Morris, C., \& Leonard, C. (1990). Hypothesis for development of a behavioral phenotype in Williams syndrome. American Journal of Medical Genetics, 37, $126-131$.

DiStefano, C., Zhu, M., \& Mindrila, D. (2009). Understanding and using factor scores: Considerations for the applied researcher. Practical Assessment, Research, \& Evaluation, 14, 1-11. 
Dodd, H. F. \& Porter, M. A. (2011a). Interpretation of ambiguous situations: Evidence for a dissociation between social and physical threat in Williams syndrome. Journal of Autism and Developmental Disorders, 41, 266-274.

Dodd, H. F. \& Porter, M. A. (2011b). There's that scary picture: Attention bias to threatening scenes in Williams syndrome. Neuropsychologia, 49, 247-253.

Dodd, H. F., Schneiring, C. A., \& Porter, M. A. (2009). Beyond behaviour: Is social anxiety low in Williams syndrome? Journal of Autism and Developmental Disorders, 39, 1673-1681.

Dunn, W. (1997). The impact of sensory processing abilities on the daily lives of young children and their families: A conceptual model. Infants \& Young Children, 9, 2335.

Dweck, C., \& Wortman, C. (1982). Learned helplessness, anxiety, and achievement motivation: Neglected parallels in cognitive, affective, and coping responses. In H.W. Kronhe and L. Laux (Eds.), Achievement, stress, and anxiety (pp. 93-125). Washington, DC: Hemisphere.

Dykens, E. (1999). Direct effects of genetic mental retardation syndromes: Maladaptive behavior and psychopathology. International Review of Research in Mental Retardation, 22, 1-26.

Dykens, E. (2003). Anxiety, fears, and phobias in persons with Williams syndrome. Developmental Neuropsychology, 23, 291-316.

Dykens, E., \& Rosner, B. (1999). Refining behavioral phenotypes: Personality and motivation in Williams and Prader-Willi syndromes. American Journal of Mental Retardation, 104, 158-169. 
Dykens, E., Rosner, B. A., Ly, R., \& Sagun, J. (2005). Music and anxiety in Williams syndrome: A harmonious or discordant relationship? American Journal on Mental Retardation, 110, 346-358.

Edelson, S. M., Edelson, G. M., Kerr, C. R., \& Grandin, T. (1999). Behavioral and physiological effects of deep pressure on children with autism: A pilot study evaluating the efficacy of Grandin's hug machine. The American Journal of Occupational Therapy, 53, 145-152.

Einfeld, S. L., \& Tonge, B. J. (1994). Manual for the Developmental Behaviour Checklist. Syndey/Melbourne, Australia: University of New South Wales/Monash University.

Einfeld, S. L., \& Tonge, B. J. (2002). Manual for the Developmental Behaviour Checklist $\left(2^{\text {nd }}\right.$ ed). Syndey/Melbourne, Australia: University of New South Wales/Monash University.

Einfeld, S. L., Tonge, B. J., \& Florio, T. (1997). Behavioral and emotional disturbance in individuals with Williams syndrome. American Journal on Mental Retardation, $102,45-53$.

Einfeld, S. L., Tonge, B. J., \& Rees, V. W. (2001). Longitudinal course of behavioral and emotional problems in Williams syndrome. American Journal on Mental Retardation, 106, 73-81.

Eisenberg, N., Cumberland, A., Spinard, T. L., Fabes, R. A., Shepard, S. A., Reiser, M.,...Losoya, N. (2001). The relations of regulation and emotionality to children's externalizing and internalizing problem behavior. Child Development, 72, 1112-1134. 
Eisenberg, N., Guthrie, I. K., Fabes, R. A., Reiser, M., Murphy, B. C., Holgren, R.,...Losoya, S. (1997). The relations of regulation and emotionality to resiliency and competent social functioning in elementary school children. Child Development, 68, 295-311.

Eldar, S., Ricon, T., \& Bar-Haim, Y. (2008). Plasticity in attention: Implications for stress response in children. Behaviour Research and Therapy, 46, 450-461.

Eley, T. C., \& Gregory, A. M. (2004). Behavioral genetics. In T. L. Morris \& J. S. March (Eds.), Anxiety disorders in children and adolescents, $\left(2^{\text {nd }}\right.$ ed.,pp. 71-97). New York, NY: Guilford Press.

Faul, F., Erdfelder, E., Lang, A., \& Buchner, A. (2007). G*Power 3: A flexible statistical power analysis program for the social, behavioral, and biomedical sciences. Behavior Research Methods, 39, 175-191.

Field, A. (2005). Discovering statistics using SPSS. Thousand Oaks, CA: Sage Publications.

First, M. B., Gibbons, M., Spritzer, R. L., Williams, J. W. B., \& Benjamin, L. (1996). User's guide for the Structural Clinical Interview for DSM-IV Axis I DisordersResearch Version. New York: Biometric Research.

Gagliardi, C., Martelli, S., Tavano, A., \& Borgatti, R. (2011). Behavioural features of Italian infants and young adults with Williams-Beuren syndrome. Journal of Intellectual Disability Research, 55, 121-131.

Gallo, F. J., Klein-Tasman, B. P., Gaffrey, M. S., \& Curran, P. (2008). Expecting the worst: observations of reactivity to sound in young children with Williams syndrome. Research in Developmental Disabilities, 29, 567-581. 
Gioia, G. A., Isquith, P. K., Guy, S. C., \& Kenworthy L. (2000). Behavior Rating Inventory of Executive Function. Child Neuropsychology, 6, 235-238.

Gjone, H., \& Stevenson, J. (1997). A longitudinal twin study of temperament and behavior problems: Common genetic or environmental influences? Journal of the American Academy of Child and Adolescent Psychiatry, 36, 1448-1456.

Goldsmith, H., Van Hulle, C., Arneson, C., Schreiber, J., \& Gernsbacher, M. (2006). A population-based twin study of parentally reported tactile and auditory defensiveness in young children. Journal of Abnormal Child Psychology, 34, 378392.

Gosch, A., \& Pankau, R. (1994). Social-emotional and behavioral adjustment in children with Williams-Beuren syndrome. American Journal of Medical Genetics, 53, 335339.

Gosch, A., \& Pankau, R. (1997). Personality characteristics and behaviour problems in individuals of different ages with Williams syndrome. Developmental Medicine and Child Neurology, 39, 527-533.

Graham, J. M., Rosner, B., Dykens, E., \& Visootsak, J. (2005). Behavioral features of CHARGE syndrome: Comparison with Down syndrome, Prader-Willi syndrome, and Williams syndrome. American Journal of Medical Genetics, 133A, 240-247.

Grant, V., Bagnell, A., Chambers, C., \& Stewart, S. (2009). Early temperament prospectively predicts anxiety in later childhood. Canadian Journal of Psychiatry, $54,320-330$. 
Green, S. A., \& Ben-Sasson, A. (2010). Anxiety disorders and sensory over-responsivity in children with autism spectrum disorders: Is there a causal relationship? Journal of Autism and Developmental Disorders, 40, 1495-1504.

Green, S. A., Ben-Sasson, A., Soto, T. W., \& Carter, A. S. (2012). Anxiety and sensory over-responsivity in toddlers with autism spectrum disorders: Bidirectional effects across time. Journal of Autism and Developmental Disorders, 42, 1112-1119.

Greenspan, S., \& Wieder, S (2005). Diagnostic manual for infancy and early childhood: Mental health, developmental, regulatory-sensory processing and language disorders and learning challenges. Bethesda, MD: Interdisciplinary Council on Developmental and Learning Disorders (ICDL). Web: http://www. icdl. org.

Heal, L., \& Sigelman, C. (1995). Response biases in interviews of individuals with limited mental ability. Journal of Intellectual Disability Research, 39, 331-340.

Hegvik, R., McDevitt, S., \& Carey, W. (1982). The middle childhood temperament questionnaire. Journal of Developmental and Behavioral Pediatrics, 3, 197-200.

Henderson, D. R., Crawford-Zelli, N. A., Woodruff-Borden, J., \& Mervis, C. B. (March, 2014). Genetic factors in psychiatric diagnoses: A comparison of children with 7q11.23 deletions (Williams syndrome) and duplications (7q11.23 duplication syndrome). Gatlingburg Conference on Research and Theory in Intellectual and Developmental Disabilities, Chicago, IL.

Hillier, L. W., Fulton, R.S., Fulton, L. A., Graves, T. A., Pepin, K. H., WagnerMcPherson, C.,...Wilson, R. K. (2003). The DNA sequence of human chromosome 7. Nature, 424, 157-165. 
Hoogenraad, C., Koekkoek, B., Akhmanova, A., Krugers, H., Dortland, B., Miedema, M.,...Galjart, N. (2002). Targeted mutation of Cyln2 in the Williams syndrome critical region links CLIP-115 haploinsufficiency to neurodevelopmental abnormalities in mice. Nature Genetics, 32, 116-127.

Iversen, S., Kupfermann, I., \& Kandel, E. (2000). Emotional states and feelings. In E. Kandel, J. Scwartz, \& T. Jessell (Eds.), Principles of neural science $\left(4^{\text {th }}\right.$ ed., pp. 982-996). New York: McGraw-Hill.

John, A. E., \& Mervis, C. B. (2010). Sensory modulation impairments in children with Williams syndrome. American Journal of Medical Genetics 154C, 266-276.

Kaiser, H. F. (1974). An index of factorial simplicity. Psychometrika, 39, 31-36.

Kashani, J. H., \& Orvaschel, H. (1990). A community study of anxiety in children and adolescents. American Journal of Psychiatry, 147, 313-318.

Kass, R. A., \& Tinsley, H. E. A. (1979). Factor analysis. Journal of Leisure Research, 11, 120-138.

Kaufman, J., Birmaher, B., Brent, D., Rao, U., Flynn, C., Moreci, P.,...Ryan, N. (1997). Schedule for affective disorders and schizophrenia for school-age childrenpresent and lifetime version: Initial reliability and validity data. Journal of the American Academy of Child \& Adolescent Psychiatry, 36, 980-988.

Kaufman, A. S., \& Kaufman, A. L. (2004). Kaufman Brief Intelligence Test (2nd ed.). Circle Pines, MN: American Guidance Services.

Keller, M., Lavori, P., Wunder, J., Beardslee, W., Schwartz, C., \& Roth, J. (1992). Chronic course of anxiety disorders in children and adolescents. Journal of the American Academy of Child \& Adolescent Psychiatry, 31, 595-599. 
Kennedy, J. C., Kaye, D. L., \& Sadler, L. S. (2006). Psychiatric diagnoses in patients with Williams syndrome and their families. Jefferson Journal of Psychiatry, 20, 22-31.

Klein-Tasman, B. P., \& Albano, A. M. (2007). Intensive, short-term cognitive-behavioral treatment of OCD-like behavior with a young adult with Williams syndrome. Clinical Case Studies, 6, 483-492.

Klein-Tasman, B. P, \& Mervis, C. B. (2003). Distinctive personality characteristics of 8-, 9-, and 10-year-olds with Williams syndrome. Developmental Neuropsychology, 23, 269-290.

Kringelbach, M. L., \& Rolls, E. T. (2004). The functional neuroanatomy of the human orbitofrontal cortex: evidence from neuroimaging and neuropsychology. Progress in Neurobiology, 72, 341-372.

Lane, S. (2002). Sensory modulation. In A.C. Bundy, S.S. Lane, \& E.A. Murray (Eds.), Sensory integration: Theory and practice ( $2^{\text {nd }}$ ed., pp. 101-122). Philadephia, PA: Davis Company.

Last, C., Hansen, C., \& Franco, N. (1997). Anxious children in adulthood: A prospective study of adjustment. Journal of the American Academy of Child and Adolescent Psychiatry, 36, 645-652.

Last, C., Perrin, S., Hersen, M., \& Kazdin, A. (1996). A prospective study of childhood anxiety disorders. Journal of the American Academy of Child and Adolescent Psychiatry, 35, 1502-1510. 
Leyfer, O., John, A. E., Woodruff-Borden, J., \& Mervis, C. B. (2012). Factor structure of the Children's Behavior Questionnaire in Children with Williams syndrome. Journal of Autism and Developmental Disabilities, 42, 2346-2352.

Leyfer, O., Woodruff-Borden, J., Klein-Tasman, B. P., Fricke, J. S., \& Mervis, C. B. (2006). Prevalence of psychiatric disorders in 4 to 16-year-olds with Williams syndrome. American Journal of Medical Genetics 141B, 615-622.

Leyfer, O., Woodruff-Borden, J., \& Mervis, C. B. (2009). Anxiety disorders in children with Williams syndrome, their mothers, and their siblings: Implications for the etiology of anxiety disorders. Journal of Neurodevelopmental Disorders, 1, 4-14.

Li, H., Roy, M., Kuscuoglu, U., Spencer, C., Halm, B., Harrison, K.,...Francke, U. (2009). Induced chromosome deletions cause hypersociability and other features of Williams-Beuren syndrome in mice. EMBO Molecular Medicine, 1, 50-65.

Lonigan, C., Carey, M., \& Finch, A. (1994). Anxiety and depression in children and adolescents: Negative affectivity and the utility of self-reports. Journal of Consulting and Clinical Psychology, 62, 1000-1008.

Lonigan, C., Phillips, B., \& Hooe, E. (2003). Relations of positive and negative affectivity to anxiety and depression in children: Evidence from a latent variable longitudinal study. Journal of Consulting and Clinical Psychology, 71, 465-481.

Lonigan, C. J., Vasey, M. W., Phillips, B. M., \& Hazen, R. A. (2004). Temperament, anxiety, and the processing of threat-relevant stimuli. Journal of Clinical Child and Adolescent Psychology, 33, 8-20.

Luer, G., Cohen, R., \& Nauck, W. (1972). Eine Kurzform der Vineland Social Maturity Scale fur minderbegabte Kinder [A short form of the Vineland Social Maturity 
Scale for less gifted children]. In D. Eggert (Ed.): Zur Diagnose der Minderbegabung [To diagnose the less talented]. Weinheim, Germany: Beltz Verlag, pp. 281-292.

March, J., Parker, J., Sullivan, K., Stallings, P., \& Connors, C. (1997). The Multidimensional Anxiety Scale for Children (MASC): Factor structure, reliability, and validity. Journal of the American Academy of Child and Adolescent Psychiatry, 36, 554-565.

Marler, J. A., Elfenbein, J. L., Ryals, B. M., Urban, Z., \& Netzloff, M. L. (2005). Sensorineural hearing loss in children and adults with Williams syndrome. American Journal of Medical Genetics, 138A, 318-327.

Mawhood, L. (1995). Autism and developmental language disorder: Implications from a follow-up in early adult life (Unpublished doctoral dissertation). University of London: London.

McIntosh, D., Miller, L., Shyu, V., \& Dunn, W. (1999). Short Sensory Profile. New York: Psychological Corporation.

Meester, C., Muris, P., \& van Rooijen, B. (2007). Relations of neuroticism and attentional control with symptoms of anxiety and aggression in non-clinical children. Journal of Psychopathology and Behavioral Assessment, 29, 149-158.

Meng, Y., Zhang, Y., Tregoubov, V., Janus, C., Cruz, L., Jackson, M.,...Jia, Z. (2002). Abnormal spine morphology and enhanced LTP in LIMK-1 knockout mice. Neuron, 35, 121-133. 
Mervis, C. B., Dida, J., Lam, E., Crawford-Zelli, N. A., Young, E. J., Henderson, D.R.,...Osborne, L. R. (2012). Duplication of $G t f 2 i$ results in separation anxiety in mice and humans. American Journal of Human Genetics, 90, 1064-1070.

Meyer-Lindenberg, A., Hariri, A., Munoz, K., Mervis, C. B., Mattay, V., Morris, C. A., \& Berman, K. F. (2005). Neural correlates of genetically determined abnormal social cognition in Williams syndrome. Nature Neuroscience, 8, 991-993.

Meyer-Lindenberg, A., Kohn, P., Mervis, C. B., Kippenhan, J., Olsen, R., Morris, C. A., \& Berman, K. F. (2004). Neural basis of genetically determined visuospatial construction deficit in Williams syndrome. Neuron, 43, 623-631.

Mian, N. D., Wainwright, L., Briggs-Gowan, M. J., \& Carter, A. S. (2011). An ecological risk model for early childhood anxiety: The importance of early child symptoms and temperament. Journal of Abnormal Child Psychology, 39, 501-512.

Milad, M., \& Rauch, S. (2007). The role of the orbitofrontal cortex in anxiety disorders. Annals of the New York Academy of Sciences, 1121, 546-561.

Miller, L., Anzalone, M., Lane, S., Cermak, S., \& Osten, E. (2007). Concept evolution in sensory integration: a proposed nosology for diagnosis. The American Journal of Occupational Therapy, 61, 135-140.

Moss, S., Prosser, H., Ibbotson, B., \& Goldberg, D. (1996). Respondent and informant accounts of psychiatric symptoms in a sample of patients with learning disability. Journal of Intellectual Disability Research, 40, 457-465.

Morris, C. A. (2010). The behavioral phenotype of Williams syndrome: A recognizable pattern of neurodevelopment. American Journal of Medical Genetics, 154C, 427431. 
Morton, J., \& Frith, U. (1995). Causal modelling: a structural approach to developmental psychopathology. Manual of Developmental Psychopathology, 1, 357-390.

Muris, P., De Jong, P. J., \& Engelen, S. (2004). Relationships between neuroticism, attentional control, and anxiety disorder symptoms in non-clinical children. Personality and Individual Differences, 37, 789-797.

Nihira, K., Foster, R., Shellhaas, M., Leland, H. (1975). AAMD Adaptive Behaviour Scale-Manual. Washington, DC: American Association for Mental Deficiency.

Ollendick, T. H. (1983). Reliability and validity of the Revised Fear Survey Schedule for Children (FSSC-R). Behavior Research and Therapy, 21, 685-692.

Ollendick, T., \& King, N. (1994). Diagnosis, assessment, and treatment of internalizing problems in children: The role of longitudinal data. Journal of Consulting and Clinical Psychology, 62, 918-926.

Ollendick, T. H., King, N. J., \& Frary, R. B. (1989). Fears in children and adolescents: Reliability and generalizability across age, gender, and nationality. Behavior Research and Therapy, 27, 321-331.

O’Reilly, M. F., Lacey, C., \& Lancioni, G. E. (2000). Assessment of the influence of background noise on escape-maintained problem behavior and pain behavior in a child with Williams syndrome. Journal of Applied Behavior Analysis, 33, 511514.

O’Reilly, M. F., \& Lancioni, G. E. (2001). Treating food refusal in a child with Williams syndrome using the parent as therapist in the home setting. Journal of Intellectual Disability Research, 45, 41-46. 
Papaeliou, C., Polemikos, N., Fryssira, E., Kodakos, A., Kaila, M., Yiota, X.,...Vrettopoulou, M. (2011). Behavioural profile and maternal stress in Greek young children with Williams syndrome. Child: Care, Health and Development, 38, 844-853.

Perez-Edgar, K., \& Fox, N. (2005). Temperament and anxiety disorders. Child and Adolescent Psychiatric Clinics of North America, 14, 681-706.

Perez-Garcia, D., Granero, R., Gallastegui, F., Perez-Jurado, L. A., \& Brun-Gasca, C. (2011). Behavioral features of Williams Beuren syndrome compared to Fragile X syndrome and subjects with intellectual disability without defined etiology. Research in Developmental Disabilities, 32, 643-652.

Pfeiffer, B., \& Kinnealey, M. (2003). Treatment of sensory defensiveness in adults. Occupational Therapy International, 10, 175-184.

Pfeiffer, B., Kinnealey, M., Reed, C., \& Herzberg, G. (2005). Sensory modulation and affective disorders in children and adolescents with Asperger's Disorder. The American Journal of Occupational Therapy, 3, 335-345.

Phillips, K. D., \& Klein-Tasman, B. P. (2009). Mental health concerns in Williams syndrome: Intervention considerations and illustrations from case examples. Journal of Mental Health Research in Intellectual Disabilities, 2, 110-133.

Porter, M. A., Dodd, H., \& Cairns, D. (2009). Psychopathological and behavior impairments in Williams-Beuren syndrome: The influence of gender, chronological age, and cognition. Child Neuropsychology, 15, 1744-4136.

Reich, W., Shayka, J. J. \& Taibelson, C. (1991). Diagnostic Interview Schedule for Children and Adolescents, parent version. St. Louis, MO: Washington University. 
Reiss, S., \& Havercamp, S. M. (1998). Toward a comprehensive assessment of fundamental motivation: Factor structure of the Reiss Profiles. Psychological Assessment, 10, 97-106.

Rende, R. (1993). Longitudinal relations between temperament traits and behavioral syndromes in middle childhood. Journal of the American Academy of Child and Adolescent Psychiatry, 32, 287-290.

Reynolds, S., \& Lane, S. J. (2009). Sensory overresponsivity and anxiety in children with ADHD. American Journal of Occupational Therapy, 63, 433-440.

Robins, L. N. (1984). Lifetime prevalence of specific psychiatric disorders in three sites. Archives of General Psychiatry, 41, 949-958.

Rodgers, J., Riby, D. M., Janes, E., Connolly, B., \& McConachie, H. (2012). Anxiety and repetitive behaviours in autism spectrum disorders and Williams syndrome: A cross-syndrome comparison. Journal of Autism and Developmental Disorders, 42, $175-180$.

Rothbart, M. K., \& Ahadi, S. A. (1994). Temperament and the development of personality. Journal of Abnormal Psychology, 103, 55-66.

Rothbart, M. K., Ahadi, S. A., Hershey, K., \& Fisher, P. (2001). Investigations of Temperament at three to seven years: The Children's Behavior Questionnaire. Child Development, 72, 1394-1408.

Rothbart, M. K., Ellis, L. K., \& Posner, M. I. (2004). Temperament and self-regulation. In R.F. Baumeister \& K.D. Vohs (Eds.), Handbook of self-regulation (pp. 357370). New York, NY: Guilford Press. 
Rozenman, M., Weersing, V. R., \& Amir, N. (2011). A case series of attention modification in clinically anxious youths. Behaviour Research and Therapy, 49, 324-330.

Rutter, M. (1967). A children's behaviour questionnaire for completion by teachers: Preliminary findings. Journal of Child Psychology and Psychiatry, 8, 1-11.

Rutter, M., Tizard, J., Whitmore, K. (Eds.). (1970). Education, Health and Behaviour. London: Longman.

Schniering, C. A., \& Rapee, R. M. (2002). Development and validation of a measure of children's automatic thoughts: The children's automatic thoughts scale. Behavior Research and Therapy, 40, 1091-1109.

Shaffer, D., Fisher, P., Dulcan, M. K., Davies, M., Piecentini, J., Schwab-Stone, M.E.,...Regier, D. A. (1996). The NIMH Diagnostic Interview Schedule for Children Version 2.3 (DISC-2.3): Description, acceptability, prevalence rates, and performance in the MECA study. Methods for the epidemiology of child and adolescent mental disorders study. Journal of the American Academy of Child and Adolescent Psychiatry, 35, 865-877.

Silverman, W. K., \& Albano, A. M. (1996). Anxiety Disorders Interview Schedule for DSM-IV, Child and Parent Versions. San Antonio, TX: Psychological Corporation.

Sofronoff, K., Attwood, T., \& Hinton, S. (2005). A randomized control trial of a CBT intervention for anxiety in children with Asperger syndrome. Journal of Child Psychology and Psychiatry, 46, 1152-1160. 
Spence, S. H. (1998). A measure of anxiety symptoms among children. Behavior Research and Therapy, 36, 545-566.

Stinson, C., Elison, S., Howlin, P. (2010). Mental health problems in adults with Williams syndrome. American Journal of Intellectual and Developmental Disabilities, 115, 3-18.

Stinson, C., Tomlinson, K., \& Estes, Z. (2012). Examining reports of mental health in adults with Williams syndrome. Research in Developmental Disabilites, 33, 144152.

Strauss, C., Frame, C., \& Forehand, R. (1987). Psychosocial impairment associated with anxiety in children. Journal of Clinical Child and Adolescent Psychology, 16, 235-239.

Susa, G., Pitica, I., Benga, O., \& Miclea, M. (2012). The self-regulatory effect of attentional control in modulating the relationship between attentional biases toward threat and anxiety symptoms in children. Cognition and Emotion, 26, 1069-1083.

Tellegen, A. (1985). Structures of mood and personality and their relevance to assessing anxiety, with an emphasis on self-report. Hillsdale, NJ: Erlbaum Press.

Tsuji, H., Miyawaki, D., Kawaguchi, T., Matsushima, N., Horino, A., Takahashi, K.,...Kiriike, N. (2009). Relationship of hypersensitivity to anxiety and depression in children with high-functioning pervasive developmental disorders. Psychiatry and Clinical Neurosciences, 63, 195-201.

Tomc, S., Williamson, N., \& Pauli, R. (1990). Temperament in Williams syndrome. American Journal of Medical Genetics, 36, 345-352. 
Turner, M. A. (1999). Annotation: Repetitive behaviours in autism: A review of psychological research. Journal of Child Psychology and Psychiatry, 40, 839-849.

Udwin, O. (1990). A survey of adults with Williams syndrome and idiopathic infantile hypercalcaemia. Developmental Medicine and Child Neurology, 32, 129-141.

Udwin, O., Howlin, P., Davies, M., \& Mannion, E. (1998). Community care for adults with Williams syndrome: How families cope and the availability of support networks. Journal of Intellectual Disability Research, 42, 238-245.

Udwin, O., \& Yule, W. (1991). A cognitive and behavioural phenotype in Williams syndrome. Journal of Clinical and Experimental Neuropsychology, 13, 232-244.

Udwin, O., Yule, W., \& Martin, N. (1987). Cognitive abilities and behavioural characteristics of children with idiopathic infantile hypercalcaemia. Journal of Child Psychology and Psychiatry, 28, 297-309.

van Lieshout, C., De Meyer, R., Curfs, L., \& Fryns, J. (1998). Family contexts, parental behaviour, and personality profiles of children and adolescents with Prader-Willi, fragile-X, or Williams syndrome. The Journal of Child Psychology and Psychiatry and Allied Disciplines, 39, 699-710.

Van Oort, F. V. A., Greaves-Lord, K., Ormel, J., Verhulst, F. C., \& Huizink, A. C. (2011). Risk indicators of anxiety throughout adolescence: The TRAILS study. Depression and Anxiety, 28, 485-494.

Velleman, S. L., \& Mervis, C. B. (2011). Children with 7q11.23 duplication syndrome: Speech, language, cognitive, and behavioral characteristics and their implications for intervention. Perspectives on Language, Learning, and Education, 18, 108116. 
Verstraeten, K., Bijttebier, P., Vasey, M. W., \& Raes, F. (2010). Specificity of worry and rumination in the development of anxiety and depressive symptoms in children. British Journal of Clinical Psychology, 50, 364-378.

Whittle, S., Allen, N. B., Lubman, D. I., \& Yucel, M. (2006). The neurobiological basis of temperament: towards a better understanding of psychopathology. Neuroscience Biobehavioral Reviews, 30, 511-525.

Woodruff -Borden, J., Kistler, D. J., Henderson, D. R., Crawford, N. A., \& Mervis, C. B. (2010). Longitudinal course of anxiety in children and adolescents with Williams syndrome. American Journal of Medical Genetics, 154C, 277-290.

Zald, D. H. (2003). The human amygdala and the emotional evaluation of sensory stimuli. Brain Research. Brain Research Reviews, 41, 88-123.

Zarchi, O., Diamond, A., Weinberger, R., Abbott, D., Carmel, M., Frisch, A.,...Gothelf, D. (in press). A comparative study of the neuropsychiatric and neurocognitive phenotype in two microdeletion syndromes: Velocardiofacial (22q11.2 deletion) and Williams (7q11.23 deletion) syndromes. European Psychiatry.

Zohar, A. H. (1999). The epidemiology of obsessive-compulsive disorder in children and adolescents. Child and Adolescent Psychiatric Clinics of North America, 8, 445460. 


\title{
CURRICULUM VITAE
}

\section{Nicole A. Crawford-Zelli, Ph.D.}

\author{
nacraw02@1ouisville.edu
}

\section{$\underline{\text { Education }}$}

Ph.D., 2013

Clinical Psychology, Department of Psychological and Brain Sciences, University of Louisville

Dissertation: Anxiety in children with Williams syndrome: Association with negative reactivity, self-regulation, and sensory modulation

Clinical Predoctoral Internship, Indiana University School of Medicine

2011-2012

Riley Hospital for Children/Larue Carter Hospital

M.A., 2008

Clinical Psychology, University of Louisville

B.A., 2004

Psychology, Keene State College

\section{$\underline{\text { Research Experience }}$}

July 2006-December 2013

Graduate Research Assistant for Carolyn B. Mervis, Ph.D., Neurodevelopmental Sciences Laboratory, University of Louisville

- Work as part of an interdisciplinary team investigating genotype/phenotype correlations in individuals with Williams syndrome or related genetic abnormalities on chromosome 7q11.23

- Assist in data collection and data management

- Design and conduct independent research projects:

- Association between sensory modulation difficulties and problems behaviors in children with Williams syndrome

- Stress in caregivers of children with Williams syndrome or Down syndrome

- Association between phenotype characteristics and anxiety in children with Williams syndrome

- Association between selective attention to affective stimuli and anxiety symptoms in children with Williams syndrome 
June 2007-December 2008

June 2004-June 2006

January 2002-May 2004

\section{Teaching Experience}

January 2009-May 2010
Graduate Research Assistant for Janet Woodruff-Borden, Ph.D., Healthy Parents-Healthy Kids Research Center, University of Louisville

- Work as part of a team investigating familial factors associated with anxiety and stress in children. Assist in data collection

- Conduct independent research project investigating the association of child temperament, maternal negative affect, and family environment with internalizing symptoms in preschool-aged children

\section{Research Assistant for Helen Tager-Flusberg, Ph.D., Lab of Developmental Cognitive Neuroscience, Boston University School of Medicine}

- Work as part of a team investigating social perception and social-emotional development of children, adolescents, and adults with Williams syndrome or Down syndrome

- Assist in data collection, grant development, experimental design and preparation, data analysis, and recruitment of participants

\section{Undergraduate Research Assistant for Lawrence} Welkowitz, Ph.D., Keene State College

- Coordinate recruitment and scheduling of participants with autism spectrum disorders for study investigating psycholinguistic patterns of speech

- Conduct independent honors program research project examining emotion identification abilities in young adults with Asperger syndrome

\section{Graduate Teaching Assistant for Patrick Shafto, Ph.D., Quantitative Methods in Psychology, University of Louisville}

- Design curriculum and instruct applied lab sections. Grade student exams, teach concepts, and provide individual instruction to students

- Guest lecturer for Regression Analysis and Factorial ANOVA 
July 2008-December 2008

January 2008-June 2008

July 2007-December 2007
Graduate Teaching Assistant for Keith Lyle, Ph.D., Quantitative Methods in Psychology, University of Louisville

- Assist in curriculum development. Instruct applied lab sections. Grade student exams, teach concepts, and provide individual instruction to students

- Design frequent-recall testing program for students in collaboration with course instructor

Graduate Teaching Assistant for Robert Meyer, Ph.D., Undergraduate Abnormal Psychology, University of Louisville

- Grade student exams and assignments, and provide supplemental instruction to students

Graduate Teaching Assistant for Christy Wolfe, Ph.D., Undergraduate Developmental Psychology, University of Louisville

- Assist in curriculum development. Grade student exams and assignments, and provide supplemental instruction to students

- Designed team-based learning curriculum for students in collaboration with instructor

\section{Honors and Awards}

Dissertation Award for the Gatlinburg Convention on Research and Theory in Intellectual and Developmental Disabilities, 2014

Stanley A. Murrell Scientist-Practitioner Award, 2011

Association for Psychological Science Student Affiliate Research Competition Winner, 2005

Academic Excellence Conference Award, Keene State College, 2004

Keene State College Alumnae Organization Travel Award, 2004

\section{Mentored Journal Reviewer}

Journal of Pediatric Psychology

Journal of Autism and Developmental Disorders

\section{$\underline{\text { Publications }}$}

Mervis, C., Dida, J., Lam, E., Crawford-Zelli, N., Young, E., Henderson, D., Onay, T., Morris, C., Woodruff-Borden, J., Yeomans, J., \& Osborne, L. (2012). Duplication of GTF2I results in separation anxiety in mice and humans. American Journal of Human Genetics.

Crawford, N., Schrock, M., \& Woodruff-Borden, J. (2011). Child internalizing symptoms: Contributions of child temperament, maternal negative affect, and family functioning. Child Psychiatry and Human Development, 42, 53-64. 
Lyle, K. \& Crawford, N. (2011). Retrieving essential material at the end of lectures improves performance on statistics exams. Teaching of Psychology, 38, 94-97.

Woodruff-Borden, J., Kistler, D.J., Henderson, D.R., Crawford, N., \& Mervis, C. (2010). Longitudinal course of anxiety in children with Williams syndrome. American Journal of Medical Genetics Part C, 153C, 277-290.

Plesa Skwerer, D., Borum, L., Verbalis, A., Schofield, C., Crawford, N., Ciciolla, L., \& TagerFlusberg, H. (2009). Autonomic responses to dynamic displays of facial expressions in adolescents and adults with Williams syndrome. Social Cognitive \& Affective Neuroscience, 4, 93-100.

Crawford, N., Edelson, L., Plesa Skwerer, D., \& Tager-Flusberg, H. (2008). Expressive language style in narratives by adolescents and adults with Williams syndrome. Applied Psycholinguistics, 29, 1-18.

\section{$\underline{\text { Posters and Presentations }}$}

Henderson, D.R., Crawford-Zelli, N., Woodruff-Borden, J., \& Mervis, C. (2012, March). Genetic factors in temperament: A comparison of children with $7 q 11.23$ deletions (Williams syndrome) and duplications (7q11.23 duplication syndrome). Paper presented as part of symposium: Biobehavioral investigations of temperament in Fragile X, Williams, and 7q11.23 duplication syndromes, $44^{\text {th }}$ Annual Gatlinburg Conference, Annapolis, MD.

Dida, J., Mervis, C., Lam, E., Crawford-Zelli, N., Young, E., Henderson, D., Morris, C., Onay, T., Woodruff-Borden, J., Yeomans, J., Osborne, L. (2011, November). Duplication of GTF2I results in separation anxiety in mice and humans. Poster presented at the $41^{\text {st }}$ Annual Meeting of the Society for Neuroscience, Washington, D.C.

Crawford, N., Woodruff-Borden, J., \& Mervis, C. (2011, March). Parenting stress in mothers of very young children with Williams syndrome. Poster presented at the 44th Annual Gatlinburg Conference, San Antonio, TX.

Henderson, D., Crawford, N., Woodruff-Borden, J., \& Mervis, C. (2011, March). Peer relationships and extracurricular activities of children with Williams syndrome: A preliminary study. Poster presented at the 44th Annual Gatlinburg Conference, San Antonio, TX.

Crawford, N., Schrock, M., \& Woodruff-Borden, J. (2008, November). Childhood internalizing disorders: Using negative affect and family functioning to predict internalizing symptoms in children aged 3 - 5 years. Poster presented at the Association for Behavioral and Cognitive Therapies' $42^{\text {nd }}$ Annual Convention, Orlando, FL.

Tammen, E., Chapman, L., Crawford, N., \& Woodruff-Borden, J. (2008, November). Mother and father acceptance: Differential impact on current anxiety symptoms in African American and European American young adults. Poster presented at the Association for Behavioral and Cognitive Therapies' $42^{\text {nd }}$ Annual Convention, Orlando, FL. 
Crawford, N., John, A., Woodruff-Borden, J., \& Mervis, C. (2008, July). Sensory processing difficulties predict internalizing symptoms, ADHD symptoms, and repetitive behaviors in 4 -10-year-old children with Williams syndrome. Poster presented at the $12^{\text {th }}$ International Professional Conference on Williams syndrome, Garden Grove, CA.

Mervis, C., Velleman, S.L., John, A.E., Currier, A., Peregrine, E., Becerra, A.M., Crawford, N., Woodruff-Borden, J., Beasley, J., \& Morris, C.A. (2008, July). Intellectual and behavioral characteristics of individuals with Williams syndrome or duplication of the Williams syndrome region. Invited platform presentation at the $12^{\text {th }}$ International Professional Conference on Williams syndrome, Garden Grove, CA.

Crawford, N., Edelson, L., Plesa Skwerer, D., \& Tager-Flusberg, H. (2007, April). Expressive quality of language in adolescents and adults with Williams syndrome. Poster presented at the Society for Research in Child Development's Biennial Meeting, Boston, MA.

Morris, C. A., Crawford, N., Pani, A. M., Fontana, K., Farwig, K., Rios, C., Kimberley, K., Hobart, H. H., Fricke, J., Peregrine, E., Mervis, C., Woodruff-Borden, J., \& Gregg, R. G. (2007, March). High resolution SNP microarray detects 16p interstitial duplication in a man with significant anxiety, mental retardation, hyperextensible joints, dysmorphic features, and hypopigmented streaks. Talk presented at the American College of Medical Genetics Annual Meeting, Nashville, TN.

Edelson, L., Crawford, N., Plesa Skwerer, D., \& Tager-Flusberg, H. (2006, July). Talking about daily events: Personal narratives of adolescents and adults with Williams syndrome. Poster presented at the $11^{\text {th }}$ International Professional Conference on Williams Syndrome, Richmond, VA.

Plesa Skwerer, D., Crawford, N., Edelson, L., \& Tager-Flusberg, H. (2006, July). Distinctive patterns of attachment and emotionality in children with Williams syndrome: Preliminary findings from parental interviews. Poster presented at the $11^{\text {th }}$ International Professional Conference on Williams syndrome, Richmond, VA.

Plesa Skwerer, D., Crawford, N., Edelson, L., \& Tager-Flusberg, H. (2006, July). Receptive and expressive prosodic abilities in adolescents and adults with Williams syndrome. Talk presented at the $11^{\text {th }}$ International Professional Conference on Williams syndrome, Richmond, VA.

Crawford, N., Borum, L., Verbalis, A., Schofield, C., Plesa Skwerer, D., \& Tager-Flusberg, H. (2005, May). Implicit processing of emotions in Williams syndrome. Poster presented at the $17^{\text {th }}$ Annual American Psychological Society Convention, Los Angeles, CA.

*Also presented at the $11^{\text {th }}$ International Professional Conference on Williams syndrome, Richmond, VA (2006, July).

Plesa Skwerer, D., Verbalis, A., Schofield, C., Borum, L., Crawford, N., \& Tager-Flusberg, H. (2005, April). Electrodermal responses to dynamic presentations of facial expressions of emotion in Williams syndrome. Poster presented at the biennial meeting of the Society for Research in Child Development, Atlanta, GA. 
Welkowitz, L., Baker, L., Welkowitz, J, \& Crawford, N. (2004, June). Developing a collegebased peer-mentoring program for individuals with Asperger syndrome. Panel discussion presented at the $3^{\text {rd }}$ Annual International Conference on Social Sciences, Honolulu, HI. 